\title{
POTOPITEV AVSTRO-OGRSKE ADMIRALSKE LADJE VIRIBUS UNITIS SKOZI ITALIJANSKO ARHIVSKO VOJAŠKO DOKUMENTACIJO
}

\author{
FOUNDERING OF THE AUSTRO-HUNGARIAN \\ FLAGSHIP VIRIBUS UNITIS THROUGH ITALIAN \\ MILITARY ARCHIVE FILES
}

Povzetek Prispevek analizira potopitev avstro-ogrske admiralske ladje Viribus Unitis 1. novembra 1918 v Pulju. Za raziskavo je bila uporabljena italijanska arhivska vojaška dokumentacija iz Rima. V članku je opisan proces nastajanja ideje o diverzantskem napadu na vojaško pristanišče v Pulju, ki je bila na začetku bolj domena posameznikov kot pa italijanskega vojaškega sistema. Idejo je najprej razvijal poročnik Raffaele Paolucci, hkrati pa je major Raffaele Rossetti pripravljal posebno tehnično napravo, poimenovano Mignatta, ki je omogočala prevoz eksploziva in tudi obeh diverzantov. Julija 1918 je bila mignatta operativna in oba diverzanta sta se intenzivno urila v postopkih vdora v pristanišče. Ukaz za akcijo je bil izdan 30. oktobra 1918, določal je potek akcije, ni pa predvidel njenega natančnega datuma. Akcija se je začela 31. oktobra 1918 in že v začetku ni potekala skladno z načrtom. Diverzantoma se je z velikimi težavami uspelo prebiti v pristanišče. Ko sta postavila eksplozivno polnjenje pod trup Viribus Unitis, so ju odkrili. Pripeljali so ju k novemu poveljniku mornarice Države SHS kontraadmiralu Janku Vukoviću - Podkapelskemu, ki sta ga opozorila o nevarnosti. Poveljnik je ukazal evakuacijo posadke in dovolil obema diverzantoma umik na varno. Ladja se je po italijanskih informacijah potopila v 20 minutah. Diverzanta sta bila po petih dneh osvobojena in v Italiji sprejeta kot heroja. Za potopitev Viribus Unitis sta sprejela veliko denarno nagrado, ki pa so jima jo mnogi oporekali. Paolucci je po vojni postal znan kirurg in podpornik fašizma, Rossetti pa je bil aktiven protifašist.

Ključne Viribus Unitis, Drăava SHS, Kraljevina SHS, avstro-ogrska mornarica, prva besede svetovna vojna, Pulj, Raffaele Paolucci, Raffaele Rossetti, Janko Vuković Podkapelski, Metod Koch. 
Abstract The article provides an analysis of the foundering of the Austro-Hungarian flagship Viribus Unitis on 1 November in Pula. The study was based on the Italian military archival documents from Rome. The article describes the process of creating the idea of a commando attack on a military port in Pula, which was in the first place more a matter of individuals rather than the Italian military system. The idea was first developed by Lieutenant Raffaele Paolucci, while Major Raffaele Rossetti prepared a special technical device called Mignatta, which enabled the transportation of explosives and both commandos. In July 1918, Mignatta was operational and both commandos were intensively trained in the procedures of port invasion. The mission order was issued on 30 October 1918 and determined the course of the campaign; however it did not provide its precise date. The campaign was launched on 31 October 1918 and failed to adhere to the plan from the very beginning. The two commandos managed to enter the port following some major difficulties. They were discovered once they planted a bursting charge under the hull of Viribus Unitis and were brought to the new Commander of the Navy of the State of Slovenes, Croats and Serbs, Admiral Janko Vuković - Podkapelski. They warned him of danger and the commander ordered the evacuation of the crew and let the two commandos retreat to safety. According to Italian information, the ship was sunk within 20 minutes. Both commandos were freed after 5 days and were considered heroes in Italy. They received a substantial amount of prize money for the foundering of Viribus Unitis, but many objected to this. After the war, Paolucci became a renowned surgeon and supporter of fascism, while Rossetti was an active anti-fascist.

\section{Key words Viribus Unitis; State of Slovenes, Croats and Serbs; Kingdom of Serbs, Croats and Slovenes; Austro-Hungarian Navy; First World War; Pula; Raffaele Paolucci; Raffaele Rossetti; Janko Vuković - Podkapelski; Metod Koch.}

Uvod $^{1}$ Oktobra in v začetku novembra 1918 se je na vseh bojiščih prve svetovne vojne že čutilo, da se približuje konec vojne. Izčrpanost in naveličanost je bila obojestranska, predvsem pa na strani centralnih sil popolna. Avstro-ogrska vojska pri tem ni bila izjema, ampak je v utrujenosti nedvomno celo prednjačila, saj je že bila notranje razkrojena velika vojaška formacija, ki so jo v primerjavi z drugimi vojskami notranje razjedala tudi močna nacionalna nasprotja. S tega stališča je bila z italijanske strani zelo cenjena zmaga pri Vittoriu Venetu le milostni udarec nekdaj mogočnemu vojaškemu kolosu, ki pa je bil samo še senca samega sebe. V primerjavi z avstroogrsko kopensko vojsko, ki je bila na kolenih, ta oznaka ni veljala za avstro-ogrsko vojno mornarico, ki je ostala nedotaknjena in bi jo s tehničnega vidika in številčnega stanja še zmeraj lahko ocenili kot zavidanja vredno silo. To je bil sicer le zunanji videz, tudi tukaj so prevladovala namreč notranja nasprotja in nacionalne in tudi socialne delitve. Upor mornarjev v Boki Kotorski je bil odsev teh nasprotij.

\footnotetext{
Za pomoč in posredovano fotografsko gradivo se zahvaljujem direktorju Zgodovinskega in pomorskega muzeja iz Pulja Gracijanu Kešacu in kustosinji muzeja Lani Bilić Skuljan. Zahvaljujem se tudi osebju Arhiva Zgodovinskega inštituta italijanske vojne mornarice $v$ Rimu za prijaznost in pomoč pri posredovanju arhivskega gradiva.
} 
O dogajanju v glavnem avstro-ogrskem vojaškem pristanišču Pulju in potopitvi avstro-ogrske admiralske ladje Viribus Unitis je bilo že veliko napisanega. Zanimivo je, da danes nekateri raziskovalci to ladjo označujejo kot prvo hrvaško admiralsko ladjo, nekateri kot admiralsko ladjo jugoslovanske vojne mornarice. Zagotovo gre $\mathrm{v}$ obeh primerih za pretiravanje, ki ne priznava mednarodnih razmer in dejanskega stanja na bojiščih, usoda avstro-ogrskega vojnega ladjevja je namreč že od začetka bila pomembno mednarodno vprašanje, ki je presegalo jugoslovansko-italijanski spor (Krizman, 1955, str. 143), ki je vedno bolj kulminiral.

Z avstro-ogrske strani so glede tega dogodka ostala le spominska pričevanja, ki si v določenih elementih celo nasprotujejo, arhivsko gradivo imajo ohranjeno le na italijanski strani. Tako arhiv Vojaškozgodovinskega inštituta vojne mornarice v Rimu hrani originalne načrte akcije, tehnične podatke o uporabljenih sredstvih in tudi zaključna operativna poročila obeh akterjev ter tudi vodje operacije. Ta poročila so pomembna, ker so bila napisana takoj po vrnitvi obeh diverzantov iz Pulja v Italijo in jih je ocenila tudi italijanska obveščevalna služba. Poznejši spomini so v nekaterih delih drugačni od teh prvih »svežih « in predvsem operativnih poročil, ki so tipično vojaška, kratka in operativna, brez pretiranih olepševanj in pretiravanj.

\section{ITALIJANSKO DELOVANJE PROTI GLAVNEMU AVSTRO-OGRSKEMU VOJAŠKEMU PRISTANIŠČU V PULJU DO SREDINE LETA 1918}

Italijanska stran je v drugi polovici leta 1918 proti Pulju, ki je bilo v tem času glavno vojaško pristanišče Avstro-Ogrske, še zmeraj gledala s spoštovanjem in tudi s strahom. Italijanska stran zagotovo ni najbolje poznala notranjega razpoloženja med avstro-ogrskimi mornarji. Vsaj nobeno ohranjeno italijansko obveščevalno poročilo iz tega obdobja tega ne potrjuje, vprašanje je tudi, koliko se je italijanski obveščevalni službi uspelo infiltrirati v vojaško pristanišče Pulj. Zelo verjetno so bili ti obveščevalni podatki sekundarni, predvsem iz mesta Pulj, ne pa tudi iz vojaškega pristanišča. Glede na ohranjena poročila so italijanska vojaška izvidniška letala vsak dan izvajala letalsko izvidovanje in fotografiranje vojaškega pristanišča v Pulju in s tem tudi nadzor avstro-ogrskega vojaškega ladjevja. Iz ohranjenega arhivskega gradiva je razvidno, da je bilo to izvidovanje izvajano v velikih razsežnostih, $\mathrm{z}$ dnevno angažiranimi 20 letali in več. 27. julija 1918 je tako izvidovanje Pulja in istrske obale v 24 urah izvajalo kar 36 letal (ACS 1). V skoraj vseh poročilih, pa čeprav so nekatera zelo kratka in brez operativnih novic, je bilo napisano »Osservate a Pola le solite 6 navi maggiori.$^{2}$

Italijanska stran je Pulj in pristanišče tudi bombardirala iz zraka, kar je izvajalo predvsem letalstvo kopenske vojske, saj mornarica ni imela v italijanskem arhivskem gradivu imenovanih »strateških« bombnikov. Tako je leta 1917 po italijanskih podatkih letalstvo kopenske vojske izvedlo sedem napadov na Pulj, pri čemer je sodelovalo 148 capronijev, ki so odvrgli 42 ton bomb. Leto pozneje pa je skupaj

»V Pulju videnih vseh šest glavnih ladij.» 
63 letal odvrglo na Pulj 13 ton bomb (Garello, 2010, str. 13). Hidroavioni vojne mornarice so le redko izvajali letalsko bombardiranje. Znan pa je primer 28. julija 1918, ko so letala vojne mornarice nad Puljem in okolico, po italijanskih poročilih, odvrgla dve toni bomb (ACS 2).

Glavnina avstro-ogrske flote je po bombardiranju Ancone maja 1915 ostala povsem neaktivna in je bila večinoma stalno nameščena v Pulju (Bubnov, 1930, str. 337). Izpostaviti je treba, da je italijanska stran takoj po vstopu v vojno začela razvijati ideje o napadih na avstro-ogrska vojaška pristanišča. Že novembra 1916 je poročnik bojne ladje Ildebrando Goiran s torpedovko ${ }^{3}$ in enim hitrim motornim torpednim čolnom MAS (Motoscafo Armato Silurante) ${ }^{4}$ napadel zaporo pri Fažanskem kanalu,vendar brez uspeha. Bolj uspešen je bil poročnik bojne ladje Luigi Rizzo, ki je decembra 1917 v tržaškem pristanišču potopil avstro-ogrsko bojno ladjo Wien. Italijanska stran je po nekaterih podatkih napad na avstro-ogrsko vojaško luko v Pulju intenzivno načrtovala že od januarja 1918 (AUSMM 1), vendar se načrtovalci na začetku nikakor niso mogli odločiti o načinu napada. Poudariti je treba, da je italijanska stran od 12. aprila 1918 do 14. maja 1918 kar šestkrat napadla puljsko pristanišče. Za ta namen je izdelala za premagovanje pristaniških ovir posebej prirejene čolne, ki so bili v nekaterih italijanskih operativnih dokumentih celo uradno poimenovani »morski tanki«. V enem primeru so napad izvedli kar s štirimi tovrstnimi plovili, 14. maja 1918 pa je temu plovilu z imenom Grillo pod poveljstvom kapitana korvete Maria Pellegrinija v Pulju uspelo prebiti štiri pristaniške ovire, vendar je bilo nato potopljeno. Ta plovila, ki so bila opremljena s torpedi, so imela posebne sisteme verig, ki so omogačili prehod prek določenih pristaniških ovir. Zaradi kontinuiranih napadov so v sredini leta 1918 v puljskem pristanišču dodatno okrepili varovanje in postavili dodatne ovire ob vhodu pristanišča in v njem (AUSMM 2). Italijanska mornarica je bila o novih ovirah v puljskem pristanišču seznanjena 13. julija 1918, ko jih je izvidniškemu letalu uspelo fotografirati (ACS 3). Pripravljena je bila skica ovir, ki je bila precej natančna glede smeri poteka ovir, manjkale pa so informacije o tipu ovir.

\section{RAFFAELE PAOLUCCI IN NJEGOVI ZAČETNI NAČRTI}

Konkreten načrt in priprave za izvedbo diverzantskega vdora v vojaško pristanišče v Pulju so se pripravljali in izvajali zadnjih šest mesecev pred njegovo izvedbo. Vse je bilo bolj ali manj povezano z iniciativo in fanatično energijo posameznikov.

Glede na določene informacije je prvi na idejo o vdoru v puljsko pristanišče $\mathrm{s}$ plavanjem prišel sanitetni poročnik Raffaele Paolucci, ki je že 13. februarja 1918 samoiniciativno začel trenirati plavanje v beneški laguni. Takrat je ocenjeval, da bi moral preplavati približno tri kilometre do vhoda v pristanišče. Voda je bila februarja za redne treninge premrzla, zato je Paolucci ponovno začel trenirati v začetku maja

\footnotetext{
Torpedni čoln.

4 Celo v strokovni literaturi se pojavljajo različni nazivi kratice MAS.
} 
1918 (AUSMM 3). Kmalu je preplaval približno štiri kilometre, ob sebi pa je imel sod, napolnjen z vodo in težak 150 kilogramov. Zelo verjetno je ocenjeval, da bo moral pri svojem podvigu s seboj »tovoriti« tudi tolikšen tovor, predvsem eksploziv. Paolucci je za projekt zainteresiral tudi višje mornariške častnike, na koncu pa je bil napoten h kapitanu bojne ladje Costanzu Cianu, ${ }^{5}$ ki mu je predstavil bolj realno sliko morebitnega podviga. Ciano je takrat zasedal dolžnost »inšpektorja « ${ }^{6} \mathrm{MAS}$ in je veljal za delavnega in zelo pogumnega mornariškega častnika.

Po Cianovi oceni bi moral v obe smeri skupaj preplavati skoraj 12 kilometrov. Paolucci je nadaljeval $\mathrm{s}$ treningom in na koncu mu je uspelo premagati osem kilometrov razdalje, konec maja pa mu je Ciano sporočil, da je to zadovoljivo in da gradijo poseben »torpedo « za to priložnost. Julija 1918 sta se prvič srečala z ladijskim inženirjem majorjem Raffaelom Rossettijem. Paolucci je pozneje po vojni ocenil, da sta bila karakterno in temperamentno čisto nasprotje in da je tudi to najbrž vplivalo na pozitivni izid akcije. Podobno je tudi Rossetti nekoč izjavil, da zagotovo nikoli ne bosta postala prijatelja, ker sta tako različna, kar se je tudi potrdilo (AUSMM 4).

\section{RAFFAELE ROSSETTI IN NJEGOV TEHNIČNI PROJEKT}

Rossetti je že dalj časa razvijal tehnično napravo, ki bi omogočila vdor v puljsko pristanišče, pri tem so mu pomagali tudi ladijski tehnik Giuseppe Sanna in nekateri drugi ladijski mehaniki oziroma strojniki. V bistvu je bilo razvito posebno plovilo, ki je lahko tovorilo večjo količino eksploziva in je imelo urejen pogon na stisnjen zrak. Po razpoložljivih podatkih sta bili pripravljeni dve tovrstni plovili, ki sta bili poimenovani Mignatta.

Diverzanta sta lahko ta »torpedo« jahala ali pa sta se ga lahko samo držala, v nekaterih primerih pa sta ga morala s plavanjem potiskati naprej. Ker je bila teža mignatte neuravnotežena, je bil pri »jahanju« diverzant na zadnjem delu do ramen v vodi. Danes je tudi na podlagi ohranjene arhivske dokumentacije težko oceniti, ali je delo na mignatti v resnici v celoti opravil Rossetti sam. Zelo verjetno ne, na kar nakazuje dopis kapitana bojne ladje Buccija iz leta 1930. Iz dokumenta ni popolnoma razvidno, v kakšni funkciji je bil Bucci v drugi polovici leta 1918, vendar je zelo verjetno opravljal delo vodje tehničnih delavnic, kjer se je mignatta tehnično dograjevala. Glede na ta dopis naj bi v zaključnem delu priprave mignatte sodelovalo več ljudi, v dopisu je naštetih pet imen, brez podpisnika. Dopis je sicer treba obravnavati s pridržkom, saj je šlo za prošnjo za naknadno izplačilo finančne

\footnotetext{
Bolj znan je njegov sin in Mussolinijev zet Galeazzo Ciano, ki je bil v drugi polovici 30. let italijanski zunanji minister in je imel velik vpliv na Mussolinija. Costanzo Ciano je bil že od začetka zelo aktiven v fašističnem gibanju, sodeloval in vodil je nasilne fašistične akcije v Livornu. V fašistični vladi je opravljal tudi funkcijo ministra za pošto in komunikacije, potem pa je bil pomemben član fašističnega parlamenta. Umrl je leta 1939, pogreba se je udeležil tudi Mussolini.

${ }^{6}$ V bistvu je funkcija »inšpektorja« pomenila vlogo neformalnega poveljnika MAS, vendar inšpektor ni imel polnih poveljniških pooblastil. Inšpektor je bil predvsem odgovoren za usposabljanje in bojno pripravljenost vojaškega rodu ali zvrsti, ki jih je lahko tudi inšpiciral.
} 
nagrade zaradi sodelovanja pri projektu, ki se je končal s potopitvijo avstro-ogrske admiralske ladje.

Konkretne priprave za vdor v Pulj so potekale štiri mesece, v tem času sta oba diverzanta ostajala vsak dan v vodi po 4-5 ur, naučila sta se premagovati različne vodne ovire, ki jih je zanju pripravljal Ciano, večkrat pa sta neopaženo vdrla tudi v vojaški del pristanišča v Benetkah, ne da bi ju stražarji opazili. Rossetti je podnevi mignatto preurejal in dopolnjeval, ponoči pa sta izvajala praktične vaje v morju. Nekaj dni pred aktivnostjo sta oba diverzanta vaje izvajala v prisotnosti admirala Paola Emilia Thaon di Revela, ${ }^{7}$ ki je izvedbo akcije odobril. Tri večere pred akcijo sta oba diverzanta vdrla v vojaško beneško pristanišče, ne da bi ju opazile straže ali oficirji, ki so bili k stražam postavljeni namensko in so vedeli, da se bo v pristanišču nekaj dogajalo.

\section{TEHNIČNE ZNAČILNOSTI MIGNATTE}

Še danes ostaja odprto vprašanje, na katerem torpedu je v resnici temeljilo oblikovanje mignatte. Po nekaterih podatkih naj bi šlo za preurejen nemški torpedo G 7, ki je bil standardni nemški torpedo iz prve svetovne vojne, ki so ga uporabljale predvsem površinske ladje (Friedman, 2011, 338). Tudi italijanske mornariške oblasti po vojni niso natančno vedele, na čem je temeljila mignatta. Šele ko so naknadno po vojni izpod trupa potopljene avstro-ogrske ladje Wien dvignili ostanke mignatte, so vojaški strokovnjaki ugotovili, da je pomemben del pripadal nemškemu torpedu $G$ 7. Leta 1930 so inženirji italijanske vojne mornarice ocenjevali, da je preostali del pripadal italijanskemu torpedu B 57, in tudi različni arhivski viri ta podatek zelo različno navajajo, tako da zadeva ni dokončna in najbrž nikoli ne bo. Leta 1930 so natančno preučili drugi primerek mignatte, ki ni bil uporabljen, ki pa leta 1930 ni bil več ohranjen v celoti, saj naj bi nekateri sestavni deli manjkali. Zelo verjetno so bili po koncu vojne $\mathrm{z}$ mignatte odvzeti in uporabljeni kje drugje.

Glede na poročilo mornariškega tehničnega oddelka iz La Spezie iz leta 1930 naj bi bila mignatta sestavljena iz treh delov. Sprednji del je bil razdeljen v dva prostora. Večji del je bil namenjen dvema eksplozivnima polnjenjema, ${ }^{8}$ manjši del pa akumulatorju, elektromagnetnemu sistemu in urnemu mehanizmu za izvedbo vžiga eksploziva. Glede na isto poročilo naj bi teža enega eksplozivnega polnjenja znašala $162,5 \mathrm{~kg}$ tritola (skupaj $325 \mathrm{~kg}$ ). Urni mehanizem je pripravilo podjetje Molinari iz Genove in je omogočal časovni zamik do šest ur. Če bi diverzant sprožil eksplozivno polnjenje za takojšnje delovanje, je urni mehanizem imel varnostni čas omejen na

\footnotetext{
Takoj po zaključku vojne je organiziral hitro italijansko zasedbo Istre in Dalmacije. Po vojni je bil eden najvplivnejših italijanskih mornariških oficirjev tako v političnem kot tudi v vojaškem smislu. Bil je edini admiral italijanske vojne mornarice, ki mu je fašistični režim zaradi vojnih zaslug podelil častni čin "grande ammiraglio (veliki admiral)«, ki ga lahko enačimo s činom maršala v italijanski kopenski vojski.

${ }^{8}$ Voriginalnih italijanskih arhivskih dokumentih se ves čas pojavlja izraz »torpedino«, kar bi v dobesednem prevodu pomenilo majhen torpedo, vendar je v kontekstu mignatte boljši izraz eksplozivno polnjenje.
} 
15 minut. V tem času bi se lahko diverzant odmaknil od kraja morebitne eksplozije. Akumulator je bil proizvod podjetja Hensnberg iz Milana.

V srednjem delu mignatte je bil rezervoar za zrak, z zmogljivostjo približno 545 litrov, ki naj bi bil del omenjenega nemškega torpeda. Prazen naj bi tehtal $440 \mathrm{~kg}$, poln pa $543 \mathrm{~kg}$. Pred rezervoarjem je bil poseben rezervoar za 58,8 litra vode. Vodni rezervoar je tehtal $50,5 \mathrm{~kg}$ in je bil zelo verjetno namenjen nujnemu uravnoteženju mignatte, vsaj tako so predvidevali italijanski mornariški tehniki v 30. letih (AUSMM 5).

Zadnji del mignatte je bil sestavljen iz treh delov. Zračni rezervoar je bil z medeninasto pločevino in kovinskimi nosilci povezan z zadnjim delom, ki je glede na večino ocen pripadal italijanskemu torpedu B 57. V prvem prekatu zadnjega dela so bili regulator zračnega pritiska, ki ga je bilo mogoče regulirati ročno, ventili za polnjenje in praznjenje zraka in prostor za olje s cevmi. V sredinskem delu so bile cevi za odvod zraka. Zrak se je odvajal v atmosfero po posebni cevčici, ki je bila med plovbo nekaj centimetrov nad gladino morja. Zavestno so se odpovedali odvodu zraka v vodo, ker bi to lažje izdalo položaj mignatte. V zadnjem delu je bil pogonski del, ki naj bi skoraj v celoti izviral iz torpeda B 57. Leta 1930 so poskušali ugotoviti tudi dejansko hitrost in avtonomijo, ki jo je mignatta dosegla med preizkusi v Beneškem zalivu. Vendar o tem ni bilo ohranjenih zapiskov, tega niso vedeli niti delavci, ki so kakor koli pomagali Rossettiju pri modifikacijah mignatte. Po teh istih podatkih iz leta 1930 je mignatta $v$ dolžino merila 7,85 metra, skupaj z eksplozivom pa naj bi tehtala $1173 \mathrm{~kg}$ (AUSMM 5).

To pomanjkljivo vedenje vojaških avtoritet dokazuje, da je bil tehnični projekt zelo verjetno skoraj v celoti zamisel ladijskega inženirja Rossettija in se nadrejene mornariške oblasti s projektom niso dosti ukvarjale. To navaja tudi Rossetti v svojih po vojni objavljenih spominih. V spominih omenja tudi, da je na idejo o pripravi posebnega diverzantskega sredstva za napad na avstro-ogrska pristanišča prišel že leta 1915, vendar so mornariške avtoritete zavrnile vse njegove ustne in pisne predloge, nekateri nadrejeni oficirji pa so ga označevali celo za norega (Rossetti, 1977, str. 23-34).

Rossetti je začel na mignatti delati že leta 1917, prvi eksperiment v morju pa je opravil 18. januarja 1918 (Rossetti, 1977, str. 33). V enem od ohranjenih dopisov, 2. decembra 1918, že omenjeni kapitan bojne ladje Bucci trdi, da mu je Ciano ukazal, naj posreduje pomoč Rossettiju, ki je imel težave pri zagotavljanju vžiga motorja mignatte. Buccijeva skupina naj bi posebej za Rossettija in Paoluccija pripravila in tudi priredila posebne zaščitne potapljaške obleke in tudi drugo opremo (AUSMM 6). Kakor koli že, v tem času je prišlo do izboljšav in julija 1918 je bilo ocenjeno, da je mignatta pripravljena. Od avgusta do oktobra 1918 so preizkušali sredstvo v Beneškem zalivu, kjer je bila sprejeta odločitev, da se motor na zračni pritisk zamenja z električnim na akumulatorje. »Zračni« motor naj bi povzročal težave pri zagotavljanju pogona (AUSMM 7), ni pa znano, ali je ta sprememba tudi 
v resnici bila izvedena. Zelo verjetno ne, ker se v vseh drugih poročilih omenja motor s pogonom na zračni pritisk, s katerim je mignatta dosegala hitrost do dveh vozlov. Pripravljena sta bila dva primerka mignatte, s kodnima nazivoma S1 in S2. Z S2 so izvedli akcijo v Pulju, S1 pa je danes v pomorskem muzeju v La Spezii. Vendar, kot je bilo že omenjeno, tudi temu edinemu ohranjenem primerku mignatte manjkajo nekateri originalni deli, saj je takoj po vojni ležala zapuščena v vojaškem skladišču, kjer so jo tudi odkrili.

Po ohranjenih arhivskih podatkih je Rossettiju pri pripravi vžigalnika eksploziva pomagal in sistem uredil vodja elektrotehničnih delavnic Principale Ubertis. Sistem vžigalnika je deloval na principu elektromagnetov, ki so bili nameščeni v komoro z eksplozivom. Skupaj je bilo oblikovanih 16 tovrstnih vžigalnikov. Od tega sta bila dva uporabljena med akcijo v Pulju, 14 drugih pa se je izgubilo in se že v medvojnem obdobju ni vedelo, kje so (AUSMM 8).

\section{UKAZ ZA IZVEDBO NAPADA NA PULJSKO PRISTANIŠČE}

Ukaz za akcijo je bil izdan 30. 10. 1918, v njem ni bil točno določen datum napada, ampakje bil čas opredeljen z definicijo: »v bližnjem prihodnjem obdobju«. Predvideno je bilo, da bosta v akciji sodelovali torpedovki 65 PN in 66 PN in tudi MAS 94 in MAS 95. Leta 1965 je poveljnik torpedovke 65 PN, takrat s činom kapitana korvete, Augusto Spagnoli, zapisal, da je Cianu predlagal, da bi formacijo vodila druga torpedovka. Bal se je namreč, da bi kovinska mignatta na njegovem krovu magnetni kompas napravila neuporaben za navigacijo. S soglasjem Ciana je bila za to vlogo določena torpedovka 66 PN. Poveljeval ji je poročnik bojne ladje Angelo Iachino, ki je imel bogate izkušnje iz navigacije ob istrski obali (AUSMM 9).

Ukazano je bilo, da se ladje zberejo pred Benetkami na lokaciji Pagoda Lido, od koder se ob 14.15 premaknejo do Punte Maestre in tu oblikujejo bojno formacijo. $\mathrm{Na}$ čelu kolone je bilo predvideno plutje že omenjene torpedovke $66 \mathrm{PN}$. Od tu bi ob 14.19 formacija s hitrostjo 15 vozlov izvedla premik v kurzu $102^{0}$ in bi po 44 preplutih navtičnih miljah ob 19.15 prišla do točke A (lat. $44^{0} 68^{\prime} 6^{\prime \prime}$, long. $12^{0} 55^{\prime}$ ), ki je bila opredeljena na vzhodni obali Jadranskega morja, vendar še zmeraj na odprtem morju. Na tej točki je bilo predvideno, da bi spremenili smer in bi v kurzu $64^{0} 30^{\prime}$ pluli

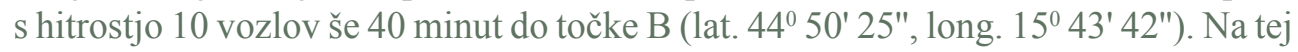
točki bi se oba diverzanta skupaj s svojo opremo in mignatto preselila s torpedovke 65 PN na MAS 95. Torpedovki bi se nato premaknili na točko Q (lat. 44 $50^{\prime}$ 30", long. $\left.15^{0} 43^{\prime} 56^{\prime \prime}\right)$, tam bi se zasidrali in čakali povratek obeh MAS. Medsebojna identifikacija ob vrnitvi MAS je bila predvidena $\mathrm{z}$ modrimi lučmi. Torpedovki bi vrnitev obeh MAS čakali do 05.00 ure zjutraj. Če se do te ure čolna ne bi vrnila, bi obe ladji odpluli do Punte Maestre. Če bi bili na tej točki na označevalni boji obešeni zastavi z inicialkama V in W, bi se torpedovki vrnili v Benetke, v nasprotnem primeru pa bi na tej točki čakali povratek obeh čolnov ali drugačnih povelj. 
Iz točke B bi oba MAS nadaljevala pot do točke C, ki je bila predvidena približno eno miljo od obale, kjer bi mignatto dali v vodo, MAS 95 bi jo vlekel za sabo, oba diverzanta bi bila v čolnu, vendar bi bila že opremljena in pripravljena za prehod v vodo. MAS 95 naj bi v ozadju spremljal MAS 94, oba čolna bi se morala s pomočjo svojih tihih elektromotorjev in ob upoštevanju morskih razmer in varnosti čim bolj približati puljskemu pristanišču. Predvideno je bilo, da bi se MAS 95 najprej zasidral 1,5 navtične milje pred Rtom Kumpar, ${ }^{9}$ kjer bi izmerili in preverili moč in smer zalivskega toka, da ne bi oviral akcije. Nato bi MAS 95 oba diverzanta pripeljal v bližino zunanje zapore na vhodu v pristanišče, vendar ta razdalja ne bi smela biti večja od ene navtične milje. Tu bi diverzanta začela samostojno pot. Iz ohranjenega načrta je jasno razvidno, da italijanska stran ni imela najboljših, niti popolnih podatkov o različnih ovirah na vhodu v puljsko vojaško pristanišče. Pričakovali in načrtovali so prehod prek dveh kompleksnih zaščitnih ovir, katerih sestave niso najbolje poznali. Usmeritve so določale, da je treba na kraju samem oceniti, ali bo mogoče $\mathrm{z}$ mignatto ovire preiti, $\mathrm{v}$ nasprotnem primeru pa izvesti premik ob ovirah in poiskati možnost vdora na mestu, na katerem so bile ovire pritrjene na obalo. Obema diverzantoma je bila, glede na količino razpoložljivega (pogonskega) stisnjenega zraka v mignatti, prepuščena odločitev o tem, katere ladje bosta napadla. Če bi bilo te pogonske mešanice še dovolj, bi napadla glavne ladje, ki so bile zasidrane globlje v pristanišču, drugače pa manjše v bližini vhoda v pristanišče. Načrtovano je bilo, da bi eksploziv namestila na dve bojni ladji. Eksplozivna naprava na prvi bi bila nameščena tako, da bi eksplodirala štiri ure po namestitvi, druga pa tri ure po eksploziji na prvi. Med obema ladjama bi moralo biti vsaj še eno plovilo, da vodni udarni val ne bi poškodoval in onemogočil nameščene eksplozivne naprave na drugi ladji. Umik bi potekal po obratnem vrstnem redu kot vhod v puljsko pristanišče. V načrtu je bilo predvideno tudi ravnanje v primeru, da napad ne bi potekal skladno z načrtom. Če bi prišlo do okvare na pogonskem delu, bi diverzanta morala s plavanjem poskusiti privleči mignatto do MAS, če pa to ne bi bilo mogoče, bi mignatto potopili in nastavili časovni mehanizem na uničenje. Če bi bila diverzanta odkrita med vstopanjem v luko in približevanjem bojnim ladjam, bi morala potopiti napravo in namestiti časovnico na aktiviranje eksploziva na eno uro. Uničenje mignatte je načrt izrecno povezoval z vojaško častjo (poudaril M. B.) obeh diverzantov. Če bi prišlo do nepredvidljivih okoliščin, zaradi katerih bi se moral MAS ali torpedovki umakniti, bi diverzanta nadaljevala akcijo in se nato poskušala rešiti na kopno. Zato sta s seboj dobila vsak po 1000 kron. Prebiti bi se morala do gozda ob obali pri Fažani. Tukaj bi ju italijansko vojaško plovilo čakalo med 00.00 in 02.00 uro od 2. do 8. novembra 1918 in nato ponovno od 28. novembra do 7. decembra 1918. Če bi bil italijanski konvoj prestrežen pri vrnitvi, bi moral takoj napasti nasprotnika, ob takem srečanju pri odhodu na nalogo pa izvedbo naloge prenesti na poznejši datum. V obeh primerih je bila kot točka zbiranja predvidena boja pri Punti Maestri. Ukaz je podpisal inšpektor MAS, kapitan bojne ladje Ciano (AUSMM 10).

\footnotetext{
9 Imenovan tudi Puljska vrata. Vitalijanskih operativnih dokumentih imenovan Capo Compare.
} 


\section{POTEK NAPADA NA PULJSKO PRISTANIŠČE}

Ukaz se je začel izvajati v noči z 31. oktobra na 1. november 1918. Akcijo je v celoti, kot je bilo predvideno, vodil kapitan bojne ladje Ciano. Skladno z načrtom so se Ciano, oba diverzanta in poveljnik obeh MAS, kapitan fregate Giovanni Battista Scapin, vkrcali na torpedovko 65 PN. Na ladji naj bi bil, po spominih Paoluccija in Rossettija (Rossetti, 1977, str. 125), prisoten tudi italijanski nacionalist in znan poet poročnik Sem Benelli, vendar drugi viri tega ne potrjujejo.

$\mathrm{Na}$ to plovilo je bila natovorjena tudi mignatta. Že ob 19.45 je prišlo do spremembe, ker sta se torpedovka 66 PN in MAS 94 morali vrniti k boji na Punta Maestra. Ob 20.15 je bila mignatta postavljena $\mathrm{v}$ morje in privezana na MAS 95. Na plovilo so se vkrcali tudi oba diverzanta in Ciano, nato pa so s pomočjo elektromotorjev začeli pluti proti Pulju. Ob 21.35 se je MAS ustavil in preverjeni sta bili moč in smer morskih tokov. Ti so dovoljevali nadaljevanje misije in pri orientaciji je zelo pomagal svetilnik na Rtu Kumpar, ki je občasno osvetlil obalo in tudi vhod v puljsko luko. Glede na vsebino operativnega poročila o izvedbi akcije sta bila v ozadju vidna tudi obrisa dveh avstro-ogrskih ladij razreda Radetzky.

Ob 22.13 je MAS 95 približno 400 metrov od vhodne pregrade izkrcal oba diverzanta skupaj z mignatto in od tu sta nadaljevala pot samostojno (AUSMM 11). Po spominih obeh glavnih akterjev je zračni pritisk v pogonski komori znašal 205 atm. ${ }^{10}$ Glede na isti vir v času priprav komore nikoli niso napolnili s tako visokim pritiskom. $\mathrm{Ob}$ 22.30 sta oba diverzanta in mignatta, ki je plula s hitrostjo dveh vozlov, prispeli do prve zunanje ovire pred varovalnim nasipom v puljsko vojaško luko.To prvo oviro so sestavljali glede na njuno poročilo trimetrski kovinski valji, ki so bili na vrhu med seboj povezani z jeklenico v razdalji približno dveh metrov. Oviro so nad gladino držali veliki plovci. Diverzanta sta začela plavati ob oviri in iskati možnost prehoda, $\mathrm{v}$ tem času sta bila osvetljena tudi z žarometom s smeri Rta Kumpar, vendar nista bila opažena. $\mathrm{V}$ istem času je povsem mimo njiju iz pristanišča izplula podmornica $\mathrm{z}$ opazovalnim stolpom nad gladino, vendar tudi tokrat nista bila opažena. Iz poročil je razvidno, da so bile ovire ob vhodu v pristanišče razvrščene v več vrstah. Diverzanta sta nato prišla do nasipa, ki so ga sestavljali betonski bloki, nametani drug na drugega, kar je bilo v njun prid, saj tako narejen nasip ponoči ni omogočal varne hoje in s tem tudi premika stražarjev. Diverzanta sta se zato zadrževala ob nasipu. Ob 00.30 uri sta bila po njuni oceni približno 200 metrov od prehoda v nasipu, ki je vodil v notranjost luke. Paolucci je opravil kratko izvidovanje vhoda v luko, ki je po spominih meril okoli 60 metrov. Paolucci se je v 15 minutah vrnil, nato sta ugasnila motor in s plavanjem nadaljevala premik proti vhodu v luko. Na majhen vhod v luko sta priplavala okoli 1.00 ure zjutraj. Vhod v luko je bil zaščiten s premično oviro, sestavljeno iz gredi, zelo verjetno lesenih. Gredi so bile postavljene v dveh vodoravnih vrstah, med njimi pa je bilo precej povezujočih gredi postavljenih v nasprotni smeri. V smeri proti morju je ovira imela tudi priostrene kovinske palice, na nekaterih od

\footnotetext{
${ }^{10}$ V originalnem dokumentu je enota zračnega pritiska označena kot atmosfera, vprašanje pa je, če je mogoče to enačiti z danes veljavno mersko enoto.
} 
njih pa so bili tudi prazni kovinski sodi, ki bi ob premikanju povzročali hrup. Vhod je varovala tudi posadka $\mathrm{z}$ majhnim topom, vendar je bil vhod verjetno zaradi nam znanega kaotičnega stanja v pristanišču v tistem trenutku slabo nadzorovan. Zato sta se diverzanta tik ob nasipu, glede na operativno poročilo približno pet metrov od topa, neopazno prebila v notranjost pristanišča. Pri tem ju ni toliko ovirala ovira, kot zelo močan morski tok, ki je tekel iz pristanišča. V nekem trenutku ju je začelo odnašati proti morju, zato je Rossetti vklopil motor mignatte, ker druge možnosti praktično ni bilo. Pričakovala sta, da ju bo motor izdal, vendar se ni zgodilo nič.

Pred tem sta dvakrat opazila tudi plovila, ki so patruljirala in izvajala nadzor notranjega dela pristanišča, vendar sta bila diverzanta $v$ tistem času na zunanji strani nasipa in zunanjih ovir, zato nista bila opažena. Po uspešnem vdoru v pristanišče sta najprej zavila desno nazaj proti nasipu z notranje strani, nato sta se usmerila v notranjost pristanišča. Okoli 2.00 ure zjutraj sta dosegla prvo notranjo oviro, ki je potekala vzporedno z nasipom. Sestavljali so jo železni valji, ki so segali do 60 centimetrov pod vodo, povezani skupaj z jeklenico, nanje pa je bila pod vodo pripeta varovalna mreža. Diverzantoma je s težavo to oviro uspelo premagati. Druga ovira istega tipa je bila deset metrov za prvo, tretja pa še nadaljnjih 10 metrov naprej. Vse ovire sta sicer uspešno prešla, med drugo in tretjo oviro sta se premikala celo 30 metrov od privezanega stražnega čolna. Glede na operativno poročilo sta nato na podoben način prešla podobne tri ovire, ki so potekale od obale pravokotno na nasip. Diverzanta sta se na tak način okoli 3.00 ure neopažena znašla v notranjosti pristanišča, orientacijo sta izvajala po spominu, saj jima je busolo zalila voda. Glede na njuno poročilo so bile ladje v vrsti in lepo osvetljene. Avstroogrske bojne ladje so bile razmeščene tako, da so bile največje in najpomembnejše bojne ladje v notranjosti pristanišča. Glede na njuno zaključno poročilo o akciji je bil razpored najpomembnejših bojnih ladij od vhoda proti notranjosti pristanišča naslednji: najprej ladje razreda Radetzky: Radetzky, Erzherzog Franz Ferdinand, Zrinyi in nato šele največje bojne ladje razreda Tegetthoff: Prinz Eugen, Tegetthoff in Viribus Unitis. Ladje razreda Radetzky so bile v temi, razreda Tegetthoff pa so bile osvetljene.

Diverzanta sta na tej točki opravila pregled plovila in v zračnem rezervoarju je bilo še 120 atm., kar je bilo dovolj za vrnitev oziroma za nadaljevanje napada brez možnosti vrnitve. Diverzanta sta se odločila za drugo možnost in se odločila najti admiralsko ladjo. Do ladje Viribus Unitis sta prispela okoli 4.30 ure zjutraj, ladja je bila zadnja v vrsti šestih ladij. Motor sta ugasnila v oddaljenosti kakih 100 metrov v smeri premca ladje. Kar 15 minut sta se trudila ločiti eksplozivno polnjenje od pogonskega dela mignatte. $\mathrm{V}$ tem času ju je močan tok zanesel proti drugi strani ladje in sta morala pozicijo popraviti s plavanjem, vklopila pa sta tudi motor in se spet premaknila proti premcu ladje. Približno 25 metrov od ladje jima je uspelo ločiti eksplozivno polnjenje od pogonskega dela. Ladji sta se približala med drugim in tretjim topom $150 \mathrm{~mm}$ gledano s krme, kjer naj bi bili po italijanskem vedenju glavni motorji in bi eksplozija pomenila zanesljivo potopitev plovila. Rossettiju je šele po 20 minutah uspelo pripraviti eksplozivno polnjenje za aktivacijo. V tem času je ob 5.15 na ladji, ki je bila vsa osvetljena, trobenta oznanila jutranjo budnico. Eksplozivno polnjenje je Rossettiju ob 5.30 uspelo tempirati za 6.30. Nato se je s plavanjem začel odmikati 
od ladje in približno 50 metrov od ladje spet naletel na Paoluccija. Poskušala sta se neopazno odmakniti od ladje, kar pa jima ni uspelo, saj ju je izsledil žaromet. V tem trenutku je Paolucci aktiviral drugo eksplozivno polnjenje, Rossetti pa je odprl dva varnostna ventila za potopitev mignatte. Aktivirala sta pogonski motor in mignatta je počasi sama odplula naprej proti starejšim ladjam in je nato eksplodirala pod staro potniško ladjo Wien, ki je v času vojne služila za namestitev posadkam nemških podmornic (Freivogel, 2003, str. 84). Wien se je potopila kmalu za Viribus Unitis.

\section{ZADNJI TRENUTKI AVSTRO-OGRSKE ADMIRALSKE LADJE VIRIBUS UNITIS}

Diverzanta sta bila na stražni čoln potegnjena ob 5.45 in takoj sta bila prepoznana kot Italijana. Čoln ju je pripeljal do stopnic na desni strani ladje Viribus Unitis, na vrhu stopnic sta zakričala »Živela Italija«, začudilo pa ju je, da nista bila sprejeta sovražno, ampak prej prijazno. Na pokrivalih navzočih mornarjev sta takoj opazila jugoslovanske oznake. Na vprašanje, kako sta prišla v pristanišče, sta po usmeritvah Ciana odgovorila, da sta prišla s hidroavionom. Glede na spremenjeno stanje, na katerega sta naletela na palubi ladje, sta se hitro odločila in zahtevala, da ju sprejme poveljnik ladje. Okoli 6.00 ure sta bila odpeljana v kapitanove prostore. Paolucci je novo imenovanemu poveljniku pomorske flote Države SHS kontraadmiralu Janku Vukoviću - Podkapelskemu ${ }^{11}$ izročil svoj nož in ga opozoril, da ladji Viribus Unitis, ki je bila po nekaterih navedbah že preimenovana v Jugoslavijo (Barle, 2013, str. 70), grozi »takojšnja in velika nevarnost«. Vuković ga je vprašal, kakšna nevarnost grozi ladji in če podobna nevarnost grozi tudi drugim ladjam. Paolucci je odgovoril, da glede tipa nevarnosti ne more odgovoriti, da pa drugim ladjam nevarnost ne grozi. Vuković si je v tistem trenutku, glede na ohranjena italijanska poročila, nadel rešilni jopič in v nemščini izdal povelje, da se ladja zapusti. Na prošnjo obeh diverzantov je Vuković dovolil, da tudi onadva zapustita ladjo, kar sta poskušala doseči s plavanjem. Podobno so se plavanjem poskušali rešiti mnogi mornarji, za pomoč je bila s svetlobnimi signali zaprošena tudi najbližja bojna ladja Tegetthoff, od koder so bili takoj poslani reševalni čolni. Ob 6.20 sta bila oba diverzanta pobrana v reševalni čoln, ki pa ju je pripeljal do lestve in sta se spet znašla na Viribus Unitis. Pričakala ju je množica jeznih mornarjev, ki jima je verbalno grozila, ni pa prišlo do fizičnih napadov. Po njunem mnenju posadka ni več verjela njunim besedam, eden od mornarjev je celo z nožem začel rezati nepremočljivo obleko z Rossettijevega telesa, takrat pa je prišlo do eksplozije. Ladja se je zelo hitro začela nagibati na desno stran. Večina mornarjev se je razbežala, nekateri pa so diverzantoma grozili, da ju bodo zaprli v prostore na ladji. Diverzanta sta v tem trenutku spet prosila poveljnika ladje, ki je stal nedaleč stran, za pomoč, in zahtevala, da se njuno dejanje razume kot vojno dejanje in da se posledično tako tudi z njima ravna. Vuković jima je ponovno dovolil zapustiti ladjo, Rossetti je v tem času že slekel razrezano nepremočljivo obleko, nato pa sta se po vrvi na levi strani v bližini krme spustila v morje, kmalu pa so ju potegnili v reševalni čoln. Paolucci je na reševalni čoln najprej porinil tudi enega mornarja, ki se je utapljal in je bil italijanske narodnosti.

${ }^{11}$ Polno ime: Janko Mihovil Aleksandar pl. Vuković Podkapelski. 
Paoluccija na začetku celo naj ne bi pustili v reševalni čoln, vendar naj bi ga nato vanj potegnil rešeni avstro-ogrski mornar (Paolucci, 1918).

Po Rossettijevi oceni je od eksplozije do prevračanja ladje minilo le 10 minut, kar je zelo malo časa. Po pričevanju Rossettija naj bi bil kontraadmiral Vuković že v vodi in naj bi plaval proč od ladje, ko so ga zadele ladijske razbitine pri preobračanju ladje. Umrl naj bi pozneje v bolnišnici. Glede Vukovića ni jasno, ali je Rossetti to osebno videl ali pozneje to informacijo dopolnil na podlagi pripovedovanj drugih. Po nekaterih drugih informacijah, ki prav tako izhajajo iz arhiva italijanske vojne mornarice, naj bi se ladja Viribus Unitis potopila le v 20 minutah.

Diverzanta sta bila prepeljana na bolniško ladjo Habsburg, kjer so ju oskrbeli, nato pa s stražo odpeljali v zapor, kjer sta ostala pet dni. V poročilu omenjata, da je bilo ravnanje z njima zelo korektno. Ko je v puljsko pristanišče vplul italijanski vojaški konvoj štirih rušilcev, petih torpedovk in štirih MAS, konvoj pa je vodila italijanska vojna ladja Ammiraglio di Saint Bon, sta bila osvobojena. Po nekaterih podatkih naj bi ta konvoj na čelni torpedovki vodil kapitan bojne ladje Ciano (La Racine, 2011, str. 21), vendar nobeden od obeh akterjev v svojih spominih ne omenja, da bi se s Cianom srečali v Pulju. Na ladji ju je zvečer 5. novembra 1918 sprejel admiral Umberto Cagni, vsi prisotni italijanski vojaki in mornarji pa so ob njunem prihodu vzklikali. Naslednje jutro sta bila prepeljana v Benetke.

\section{ROSSETTI IN PAOLUCCI PO VOJNI}

Zanimiva je usoda obeh diverzantov po vojni. Takoj po vojni sta veljala za vojna junaka, kar sta tudi nedvomno bila. Paolucci je leta 1919 zapustil vojaško službo in prešel v rezervo. Posvetil se je medicini in politiki. Predaval je na univerzah v Parmi, Bologni in Rimu, v svoji karieri pa je v Italiji opravil tudi nekaj kirurških posegov, ki veljajo za pionirske (Picardi, 1992). Vse do leta 1943 je bil aktiven član fašistične stranke in bil izvoljen tudi $\mathrm{v}$ fašistični parlament. Nasprotno pa je njegov kolega Rossetti pozneje, ko je bil leta 1919 na svojo željo demobiliziran, postal odkrit antifašist, emigriral je v Pariz, od koder je bil zelo dejaven v antifašističnem gibanju. V času španske državljanske vojne je bil v Barceloni in je sodeloval v propagandi vojni na strani republikancev. Posledično mu je fašistična Italija odvzela vsa priznanja, ki so mu bila podeljena zaradi podviga v Pulju. Pravice do zasluženih priznanj so mu bile vrnjene šele po letu 1945 (Rainero, 1989).

Italijanski uspeh in potopitev ladje Viribus Unitis sta takoj po koncu vojne sprožila velike polemike, ki so bolj ali manj potekale ves čas med obema vojnama. Predvsem jugoslovanska stran je italijanski strani očitala, da je izvedla napad na puljsko pristanišče po že razglašenem premirju, kar so povzeli tudi nekateri drugi pisci. Italijanska stran je na vse tovrstne težnje in pisanja odločno in nedvoumno odgovorila in pri tem se je intenzivno vključevalo tudi vojaško diplomatsko osebje. Tako je bila maja 1929 v eni izmed ameriških strokovnih vojaških mornariških publikacij v članku o potopitvi ladje 
Viribus Unitis napisana tudi ta sporna trditev (AUSMM 12). Italijanski mornariški vojni ataše je proti navedbi ostro protestiral in zahteval popravek (AUSMM 13).

\section{FINANČNA NAGRADA ZA POTOPITEV LADJE VIRIBUS UNITIS}

Oba diverzanta sta za svoje dejanje, ki je nedvomno bilo herojsko, prejela tudi veliko denarno nagrado. Italijanska vojna mornarica je namreč v primeru potopitve sovražnikovega plovila predvidevala nagrado akterju potopitve v vrednosti dveh odstotkov ocenjene vrednosti sovražnikovega plovila. Narejena je bila posebna lestvica in na vrhu je bila prav bojna ladja Viribus Unitis, predvidena nagrada zanjo je bila 1.300.000 lir. ${ }^{12}$ To visoko nagrado so obema diverzantoma mnogi zavidali in na različne načine poskušali dokazati, da so intenzivno sodelovali pri projektu. Rossetti je kar eno poglavje svojih spominov namenil svojemu »boju za resnico« (Rossetti, 1977, str. 85-100). Tako se s to odločitvijo ni strinjala posadka MAS 95 in zelo verjetno je $\mathrm{v}$ njenem imenu ugovor vojaškim mornariškim oblastem podal poveljnik kapitan fregate Scapin, ki je poveljeval obema MAS v tej akciji. Pritožbo je 9. 2. 1919 obravnavala posebna komisija, ki jo je imenoval poveljnik vojaške pomorske baze $\mathrm{v}$ Benetkah in je bila sestavljena iz dveh kapitanov bojne ladje, vodil pa jo je mornariški visoki častnik čina podadmiral. ${ }^{13}$ Iz zaključnega poročila komisije je razvidno, da so Scapin in zelo verjetno tudi preostali pripadniki MAS svojo aktivnost in tveganje po pomembnosti enačili s tveganjem obeh diverzantov. Komisija je to argumentirano, predvsem pa povsem upravičeno, zavrnila (AUSMM 14). Z razdelitvijo nagrade se zagotovo ni strinjal tudi Ciano, ki pa ni nastopil odkrito, ampak se je za svoj kos »pogače« boril iz ozadja in pri tem uporabil tudi svoje močne politične in vojaške zveze. 29. marca 1919 je tako Uradni list Kraljevine Italije javno objavil odločitev vojaških mornariških oblasti, da se nagrada enako razdeli med Ciana, Paoluccija in Rossettija. Rossetti sicer v svojih spominih izraža spoštovanje do Ciana, vendar je prav v njih mogoče zaznati, da je Ciano igral dvojno igro. V medsebojnem dopisovanju je Rossettiju izražal vse priznanje, v ozadju pa je zelo verjetno deloval zase. Ciano naj bi tako za svoje interese lobiral celo pri italijanski delegaciji na mirovni konferenci v Parizu. Rossettiju je šele konec leta 1919 uspelo dokazati, da je bil tehnični projekt njegov in ne Cianov.

Sklep Pravno gledano je bil napad na Viribus Unitis povsem legitimno vojaško dejanje italijanske vojne mornarice in so posledično vsa ugibanja in celo čustvena obtoževanja povsem neprimerna. Avstro-Ogrska je še zmeraj obstajala in ta država je bila še zmeraj formalno v vojni tako s Kraljevino Italijo kot tudi z drugimi antantnimi silami. Narodno Vijeće iz Zagreba je sicer že 29. oktobra 1918, tj. na dan njegovega formalnega nastanka, od vojnega ministrstva na Dunaju zahtevalo, da preda vojno mornarico Državi SHS (DAH 1), kar se je formalno dan pozneje tudi zgodilo (Glaise-Horstenau, 1930, 274). Vendar je prevzem ladij od predstavnikov Narodnega Vijeća bilo formalno gledano

\footnotetext{
${ }^{12}$ Leta 2008 vrednost približno 1,7 milijona EUR (Brunetti, 2009).

${ }^{13}$ Čin »podadmiral« (sottoammiraglio) je v italijanski vojni mornarici obstajal od avgusta 1918 do novembra 1923 in je bil vmesni čin med kapitanom bojne ladje in kontraadmiralom. Čin so enačili s činom brigadirja v kopenski vojski.
} 
notranje avstro-ogrsko vprašanje in s tega stališča je tudi potopitev Viribus Unitis treba razumeti kot legitimno vojno dejanje. Res pa je, da je italijanska stran že 31. oktobra 1918 zagotovo bila obveščena o dogajanju v Pulju. Tega dne sta namreč tako zagrebško Narodno Vijeće kot tudi narodni odbor iz Pulja posredovala brzojavko antantnim vladam, vključno z italijansko, kjer je bilo opisano spremenjeno stanje v glavni avstroogrski luki (DAH 2; Krizman, 1955, str. 141; Primicerj, 1983, str. 197). S tega stališča so bile vse žrtve, kot posledica potopitve Viribus Unitis, povsem nepotrebne.

Z avstro-ogrske oziroma jugoslovanske strani pisnih poročil o potopitvi ladje Viribus Unitis ni. Avstro-ogrska vojaška oblast je že razpadla, jugoslovanska oblast pa je bila bolj nominalna kot dejanska. Že 29. oktobra 1918 sta v Pulju prevladovala kaos in nedisciplina (Grakalić, 1968, str. 727). Ko je floto 31. oktobra 1918 ob 16.30 zapustil še njen zadnji avstro-ogrski poveljnik admiral Miklós Horthy (Shepherd, 1981, str. 316), sta zagotovo disciplina in odgovornost med moštvom še dodatno popustili. To je bil pomemben element uspešnosti italijanske akcije, predvsem pa zelo hitre potopitve admiralske ladje. O tem priča poročilo admirala Cagnija iz 11. novembra 1918, v katerem je pisal o skupni večerji s kontraadmiralom Metodom Kochom ${ }^{14}$ in njegovim načelnikom štaba poročnikom bojne ladje Veljkom Budisavljevićem. Glede na to poročilo je kontraadmiral Koch izjavil, naj bi Viribus Unitis imel vsa vodotesna vrata med posameznimi podpalubnimi prekati odprta, kar je bilo vzrok, da je ladja potonila le v 20 minutah. To naj bi bilo posledica anarhije in nediscipline, ki je prevladala med posadko. Po Kochu naj ne bi bilo tudi nič narejenega, da bi se ladja rešila. V poročilu je zapisano, da je bil Koch kot kapitan fregate imenovan za vodjo vojaškega komiteja mornarjev (glej tudi: Bjelajac, 1988, str. 30), za katerega v poročilu izrecno piše, da naj bi bil »sovjetskega« tipa. ${ }^{15} \mathrm{Na}$ tej večerji naj bi Koch izjavil: »Dobro sem vedel, da se bo med posadkami organiziralo revolucionarno gibanje, kar bi posledično pomenilo anarhijo, kar bo težava za floto, ki smo jo želeli obdržati nedotaknjeno. Ko se je gibanje začelo, smo želeli posredovati radijski telegram vsem vpletenim z zahtevo po končanju sovražnosti in za takojšnjo intervencijo antante. $\mathrm{Z}$ začetkom tega gibanja je prenehala tudi avstro-ogrska oblast in jaz sem v tem smislu pripravil komunike v francoskem jeziku. Vendar do distribucije ni prišlo, ker ji je nasprotoval »doktor-poet «, ${ }^{16}$ ki je prišel iz Zagreba s polnimi pooblastili tam nastale vlade [Narodno Vijeće, op. M. B.]. 48 ur pozneje je Viribus Unitis 'zletel v zrak', za kar krivim omenjenega človeka, ki ga več ne vidim, ker je takoj odšel iz Pulja« (AUSMM 15).

\footnotetext{
${ }^{14}$ Metod Koch je po nekih informacijah ob razpadu Avstro-Ogrske imel čin kapitana korvete, po drugih navedbah pa čin kapitana fregate. 2. novembra 1918 ga je Narodno Vijeće iz Zagreba imenovalo za poverjenika za mornarico in ga povišalo v kontraadmirala. Ta čin je zadržal tudi ob prehodu v Vojsko Kraljevine SHS. Po navedbi Mileta Bjelajca naj bi bil po smrti Vukovića imenovan tudi za poveljnika flote (Bjelajac, 2004, str. 181). Njegova vloga v Pulju med 1. in 5. novembrom 1918, posebej pa predvsem glede prihoda Italijanske vojske v Pulj, je zelo nejasna in kontradiktorna.

${ }_{15}$ Šlo je za Narodni odbor, ki je bil glede na poziv Narodnega Vijeća iz Zagreba oblikovan v Pulju. Koch je bil zelo aktiven član tega odbora.

${ }_{16}$ Ni gotovo, na koga se ta opazka nanaša, zelo verjetno je šlo za neznanega predstavnika Narodnega Vijeća iz Zagreba. 31. oktobra 1918 je namreč v Pulju prišlo do sestanka med predstavniki puljskega narodnega odbora in predstavniki Narodnega Vijeća iz Zagreba. Temeljno vprašanje je bilo, »ali pozvati antantne enote, da zasedejo Pulj«.
} 


\section{Literatura}

\section{Arhivski neobjavljeni viri}

1. ACS 1 -Archivio Centrale dello Stato (Centralni državni arhiv), Rim, fondo: Real casa 1829-1951/Ufficio del primo aiutante di campo 1865-1946, busta. 14, fascicolo 1, Bolletttino informazioni circa le operazioni navali, terrestri ad aeree dal $8^{h}$ del 27 alle $8^{h}$ del 28 luglio 1918.

2. ACS 2 - Archivio Centrale dello Stato, Rim, fondo: Real casa 1829-1951/Ufficio del primo aiutante di campo 1865-1946, busta. 14, fascicolo 1, Bolletttino informazioni circa le operazioni navali, terrestri ad aeree dal $8^{h}$ del 29 alle $8^{h}$ del 30 luglio 1918.

3. ACS 3-Archivio Centrale dello Stato (ACS), Rim, fondo: Real casa 1829-1951/Ufficio del primo aiutante di campo 1865-1946, busta. 14, fascicolo 1, Nuova sistemazione delle ostruzioni di Pola adottata dopo il raid del com. .e Pellegrini (Dalle fotografie eseguite il 13 luglio 1918).

4. AUSMM 1 -Archivio Ufficio Storico della Marina Militare (Arhiv zgodovinskega inštituta italijanske vojne mornarice), Rim, fondo: Raccolta di base, busta 1212, fascicolo 3, 12. 9. 1940.

5. AUSMM 2 - Archivio Ufficio Storico della Marina Militare, Rim, fondo: Raccolta di base, busta 1212, fascicolo 3, Forzamento di Pola compiuto dalla Mignatta (notte 31 ottobre-1 novembre 1918).

6. AUSMM 3 - Archivio Ufficio Storico della Marina Militare, Rim, fondo: Raccolta di base, busta 1212, fascicolo 3, Relazione del Capitano Medico Raffaele Paolucci sulla spedizione a Pola contro la »Viribus Unitis«.

7. AUSMM 4-Archivio Ufficio Storico della Marina Militare, Rim, fondo: Raccolta di base, busta 1212, fascicolo 3, Relazione del Capitano Medico Raffaele Paolucci sulla spedizione a Pola contro la »Viribus Unitis«.

8. AUSMM 5 - Archivio Ufficio Storico della Marina Militare, Rim, fondo: Raccolta di base, busta 1212, fascicolo 3, Funzionamento dell'apparecchio Mignatta, Da documenti ricevuti dal Comando in Capo del Dipartimento Marittimo di Spezia col foglio n. 11225 del 24 marzo 1930.

9. AUSMM 6-Archivio Ufficio Storico della Marina Militare, Rim, fondo: Raccolta di base, busta 1212, fascicolo 3, Apparecchio a tempo per esplosioni di torpedini da getto, Venezia 2 dicember 1918.

10. AUSMM 7 - Archivio Ufficio Storico della Marina Militare, Rim, fondo: Raccolta di base, busta 1212, fascicolo 3, Barchino »Mignatta«.

11. AUSMM 8-Archivio Ufficio Storico della Marina Militare, Rim, fondo: Raccolta di base, busta 1212, fascicolo 3, 9. 4. 1930.

12. AUSMM 9 -Archivio Ufficio Storico della Marina Militare, Rim, fondo: Raccolta di base, busta 1212, fascicolo 3, Dichiarazione rilasciata dal capitano di vascello Augusto Spagnoli, chenel 1918, era capitano di corvetta, comandante della Squadriglia Torpediniere e della Torpediniera 65 PN a Venezia. Roma, 24 maggio 1965.

13. AUSMM 10 - Archivio Ufficio Storico della Marina Militare, Rim, fondo: Raccolta di base, busta 1212, fascicolo 3, Missione a Pola, Venezia 30 ottobre 1918.

14. AUSMM 11 - Archivio Ufficio Storico della Marina Militare, Rim, fondo: Raccolta di base, busta 1212, fascicolo 3, L'affondamento della Viribus Unitis.

15. AUSMM 12 - Archivio Ufficio Storico della Marina Militare, Rim, fondo: Raccolta di base, busta 1212, fascicolo 3, Circa l'affondamento della »Viribus Unitis«.

16. AUSMM 13 - Archivio Ufficio Storico della Marina Militare, Rim, fondo: Raccolta di base, busta 1212, fascicolo 3, My dear Captain MacFall, May 11, 1929.

17. AUSMM 14 - Archivio Ufficio Storico della Marina Militare, Rim, fondo: Raccolta di base, busta 1212, fascicolo 3, Esame dell'esposto del capitano di fregata G. B. Scapin.

18. AUSMM 15 - Archivio Ufficio Storico della Marina Militare, Rim, fondo: Raccolta di base, busta 1212, fascicolo 3, Il racconto dell'affondamento", Il vice ammiraglio Comandante in Capo Fto Cagni. 
19. DAH 1 - Državni arhiv Hrvatske, Zagreb, fond Narodno Vijeće Slovenaca, Hrvata i Srba, škatla 4, Predsjedništvo, opći spisi, god. 1918, 1205-1.

20. DAH 2 - Državni arhiv Hrvatske, Zagreb, fond Narodno Vijeće Slovenaca, Hrvata i Srba, škatla 4, Predsjedništvo, vanjsko-politička djelatnost, god. 1918, 1.

\section{Literatura}

1. Barle, A., 2013. Cesarsko-kraljevi ponos, ladje razreda Tegetthoff. V: Na fronti, revija za vojaško zgodovino. 8, str. 63-70. Nova Gorica: Društvo Soška fronta.

2. Bjelajac, M., 1988. Vojska Kraljevine SHS 1918-1921. Beograd: Narodna knjiga.

3. Bjelajac, M., 2004. Generali i admirali Kraljevine Jugoslavije 1918-1941. Beograd: Istitut za noviju istoriju Srbije.

4. Brunetti, A., ur., 2009. Il valore della moneta in Italia dal 1861 al 2008. Roma: Istituto Nazionale di Statistica.

5. Bubnov, A., 1930. Istorija pomorske ratne veštine. Dubrovnik: Štamparija Jadran.

6. Freivogel, Z., 2003. Austrougarski bojni brodovi I. svjetskog rata. Rijeka: Adamić d.o.o.

7. Friedman, N., 2011. Naval Weapons of World War One. Guns, Torpedoes, Mines and ASW Weapons of all Nations. Yorkshire: Seaforth Publishing.

8. Garello, G., 2010. L'idroaviazione italiana nella Grande Guerra. V: Storia Militare. 18/198, str. 4-15. Parma: Tuttostoria.

9. Glaise-Horstenau, E., 1930. The collapse of the Austro-Hungarian Empire. London/ Toronto: J. M. Dent and sons LTD.

10. Grakalić, M., 1968. Zapovjedi Jugoslovanske ratne mornarice u Puli. V: Pomorski zbornik. 6, str. 725-737. Zadar: Društvo za proučavanje i unapređenje pomorstva Jugoslavije.

11. Krizman, B., 1955. Dr. Ferdo Čulinović, 1918. Na Jadranu. V: Historijski zbornik. VIII/14, str. 139-145. Zagreb: Povijesno društvo Hrvatske.

12. La Racine, R. B., 2011. In Adriatico subito dopo la vittoria. V: Storia Militare. 19/210, str. 16-23. Parma: Tuttostoria.

13. Moro, T., 2011. Viribus Unitis: ultimo atto. V: Bollettino d'Archivio dell'Ufficio Storico della Marina Militare. 25/Marzo 2011, str.4-44. Roma: Archivio dell'Ufficio Storico della Marina Militare Italiana.

14. Paolucci, R., 1918. Relazione del capitano medico Raffaele Paolucci sulla spedizione a Pola contro la Viribus Unitis. V: Annali di medicina navale e coloniale. 24/2, fasc.5-6. Roma: Direzione Generale della Sanità Militare Marittima.

15. Picardi, N., 1992. Raffaele Paolucci Di Valmaggiore. V: Annali italiani di chirurgia. 63/6, str. 835-839. Roma: Edizione Luigi Pozzi.

16. Primicerj, G., 1983. 1918 cronaca di una disfatta, testi e documenti Austriaci sul crollo militare dell'impero absbugico. Milano: Arcana editrice.

17. Rainero, R., 1989. Raffaele Rossetti. Dall'affondamento della "ViribusUnitis" all'impegno Antifascista. Milano: Marzorati.

18. Rossetti, R., 1977. Contro la Viribus Unitis. La Spezia: Museo Tecnico Navale di La Spezia.

19. Shepherd, B. G., 1981. November 1918. Boston/Toronto: Little, Brown and Company. 
Figures

Matjaž Bizjak: FOUNDERING OF THE AUSTRO-HUNGARIAN FLAGSHIP VIRIBUS UNITIS THROUGH ITALIAN MILITARY ARCHIVE FILES

Slika 1:

Podpis kapitana

bojne ladje

Costanza

Ciana pod

ukaz za napad

na vojaško

pristanišče $v$

Pulju

Vir:

AUSMM

Figure 2:

Signature of

Captain Cian

Constanza

on the order

to attack the

military port in

Pula

Source:

AUSMM
30) Qualeisel asione ahe lo toxpeolntere od 1 las ohe stasioarno nol_

Ia zona antiotante in Plazsa nenios, fostero obbligate ad enpleoure per

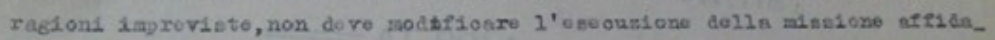

ta all'appareoohio speoirle. In tal onso gll vellolall ohe 10 guldano, ad opurazione oompluts, oerohe ramo di prender terra e di dare1 alla osaparas, per tale eventenza sono prorveduti ogmuno as rooo oorone e cli opportunt ragsuagli.

G11 operatori terramo presento ohe prendena la oargegna potramo escere ritirati alla scokliera nord del bosoo di rontane (sooglio Rovers) dolla nezsanotte alle due delle notti conprese dsl 2 all' 8 e dai. 28 novomire al 7 del prossimo dicembre, se 10 condisioni del nere 10 concon_ tono.

40) Qualora 10 unitì del convoglio avvietaseero turitì nealohe procederanno song'altro all'attacoo di ese e se L'arristanento arvenisse durante $I^{\prime a n d a t a, I ' o p e r a z i o n e ~ d o v r a ̀ ~ r i t e n e r s i ~ r i n v i a t a . ~ I n ~ o g m ~}$ oventualiti 11 punto di riunione sard is boa di p.liaetrs.

\section{OAPITAIIO DI VASOEILLO}

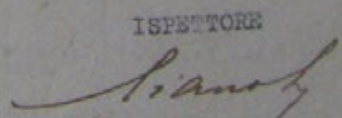

Slika 2:

Načrt posebnih nepremočljivih oblačil, ki so

bile posebej pripravljene za oba diverzanta

Vir:

AUSMM

Figure 2: Plan for special water-proof outfits specially

designed

for the two commandos.

Source:

AUSMM

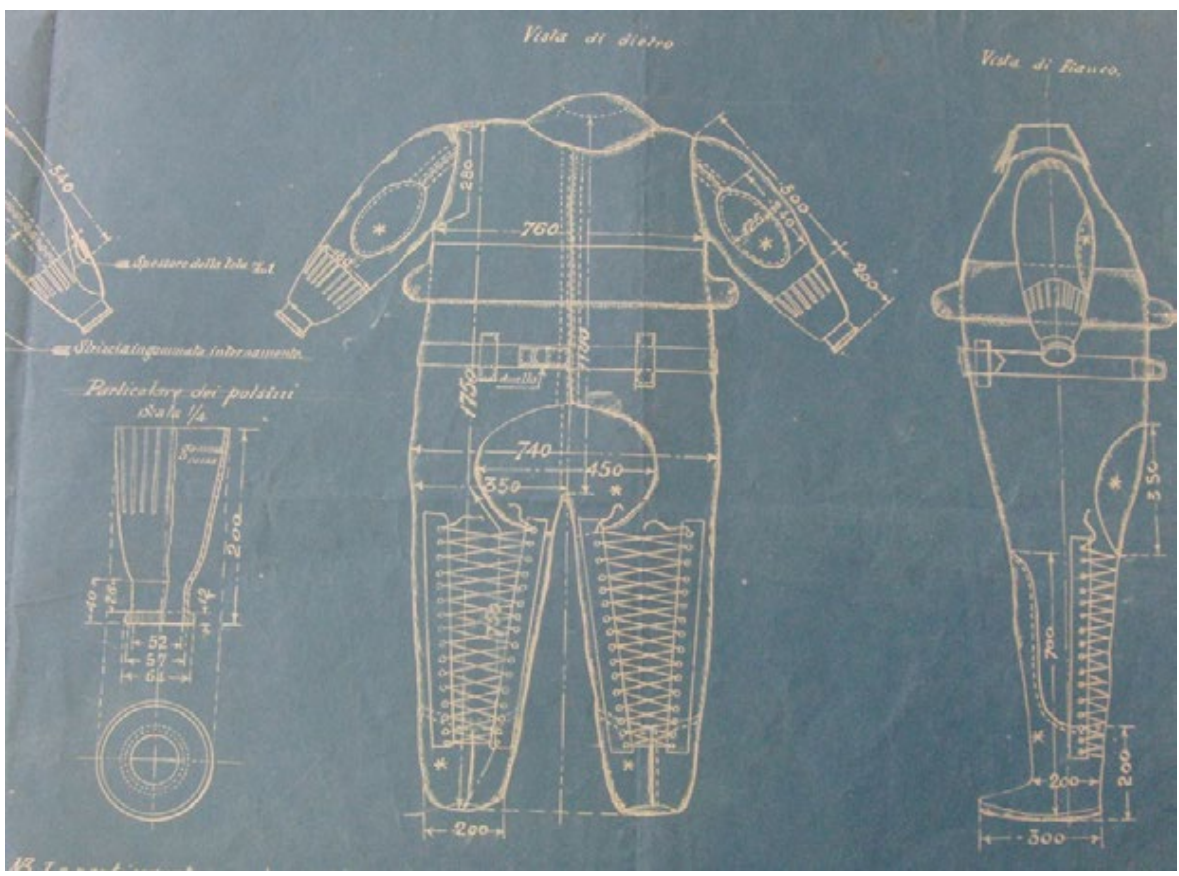


Slika 3:

Načrt urnega

mehanizma za

vžig eksploziva

na mignatti

AUSMM

Figure 3:

Design of

a clock

mechanism used

to set off the

explosives on

the Mignatta.

Source:

AUSMM

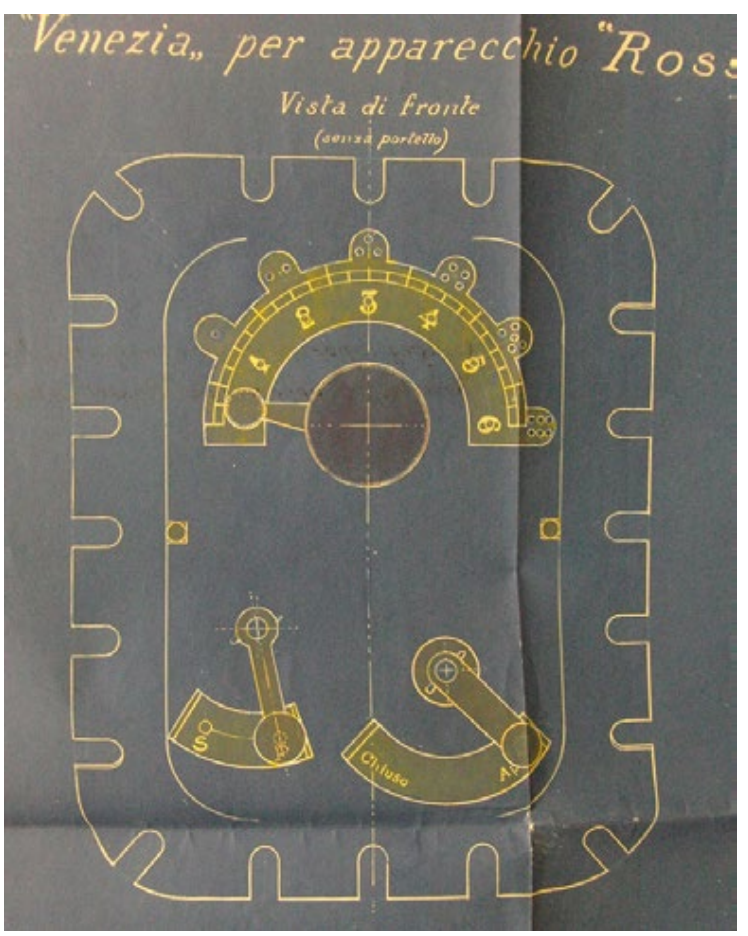

Slika 4:

Fotografija

urnega

mehanizma za

vžig eksploziva

na mignatti

Vir:

AUSMM

Figure 4: Photograph

of clock

mechanism to set off the explosives on the Mignatta

Source:

AUSMM.

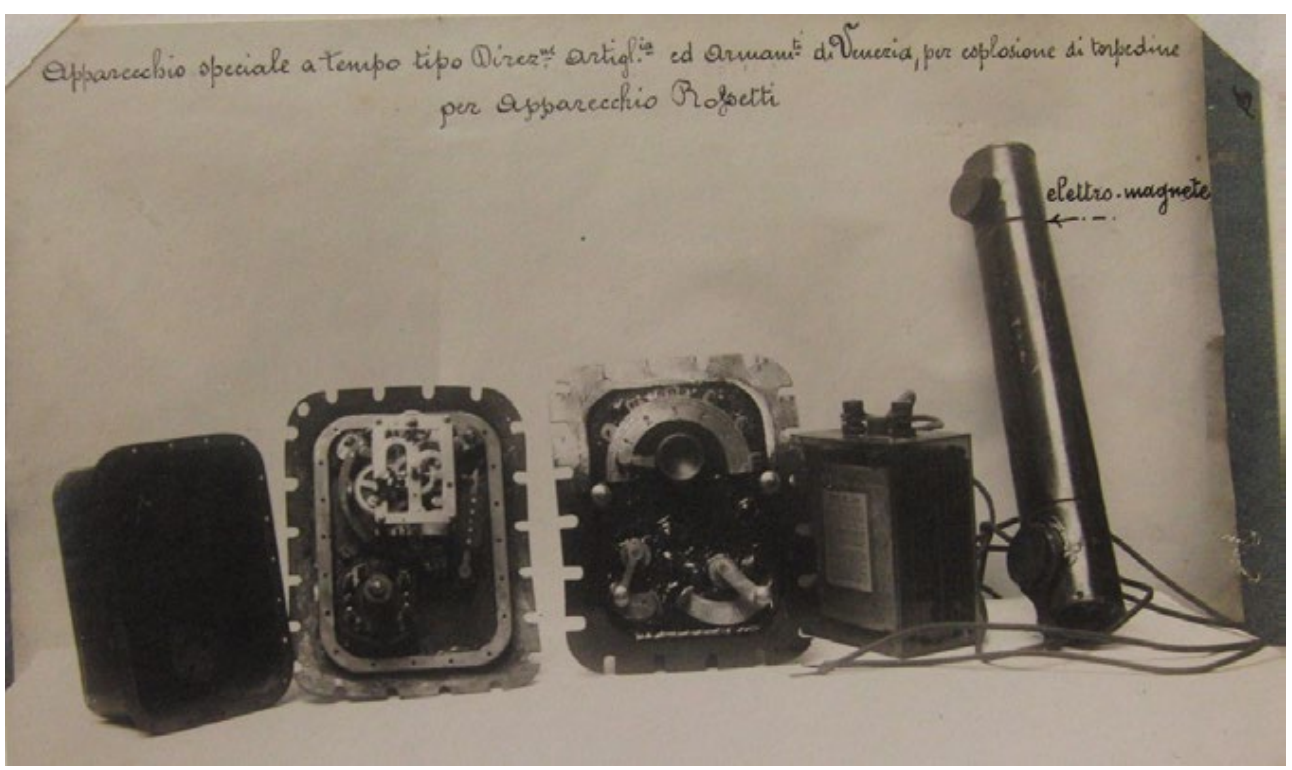


Slika 5:

Razpored avstro-

ogrskih bojnih

ladij in drugih plovil v puljskem pristanišču pred

junijem 1918

Vir:

ACS

Figure 5: Arrangement

of Austro-

Hungarian

battleships and other vessels in the Pula military port before June

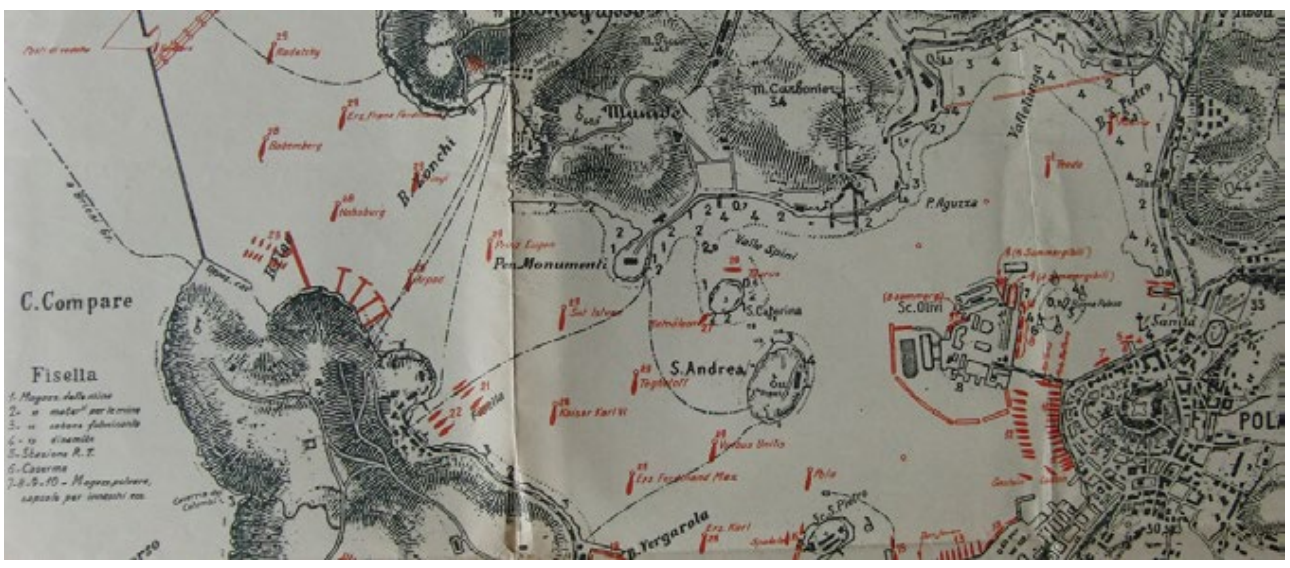
1918.

Source: ACS

Slika 6:

Smer vdora

obeh

diverzantov.

Skica dodana

poročilu o

napadu.

Vir:

AUSMM

Figure 6: Direction of invasion of both commandos. The scheme is attached to the report on the attack.

Source:

AUSMM

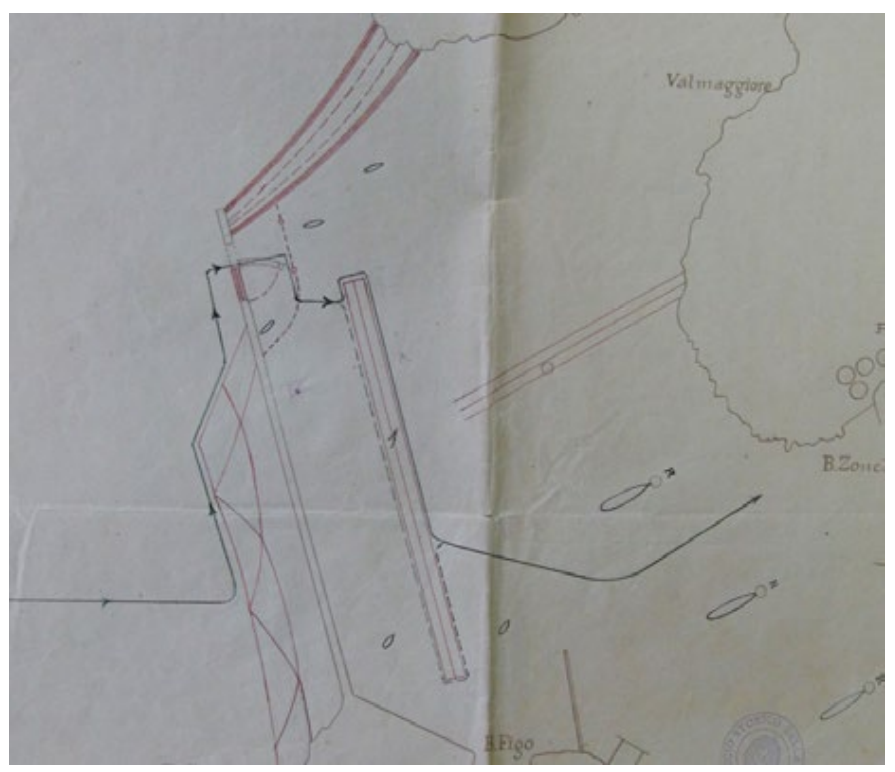


Slika 7: Sidri avstro-ogrskih bojnih ladij Viribus Unitis (desno) in Tegetthoff (levo) pred palačo nekdanjega ministrstva vojne mornarice $v$ Rimu

Matjaž Bizjak 2010

Figure 7: Anchors of AustroHungarian battleships Viribus Unitis (right) and Tegethoff (left) in front of the palace of the former Ministry of Navy in Rome

Source:

Matjaž Bizjak, 2010

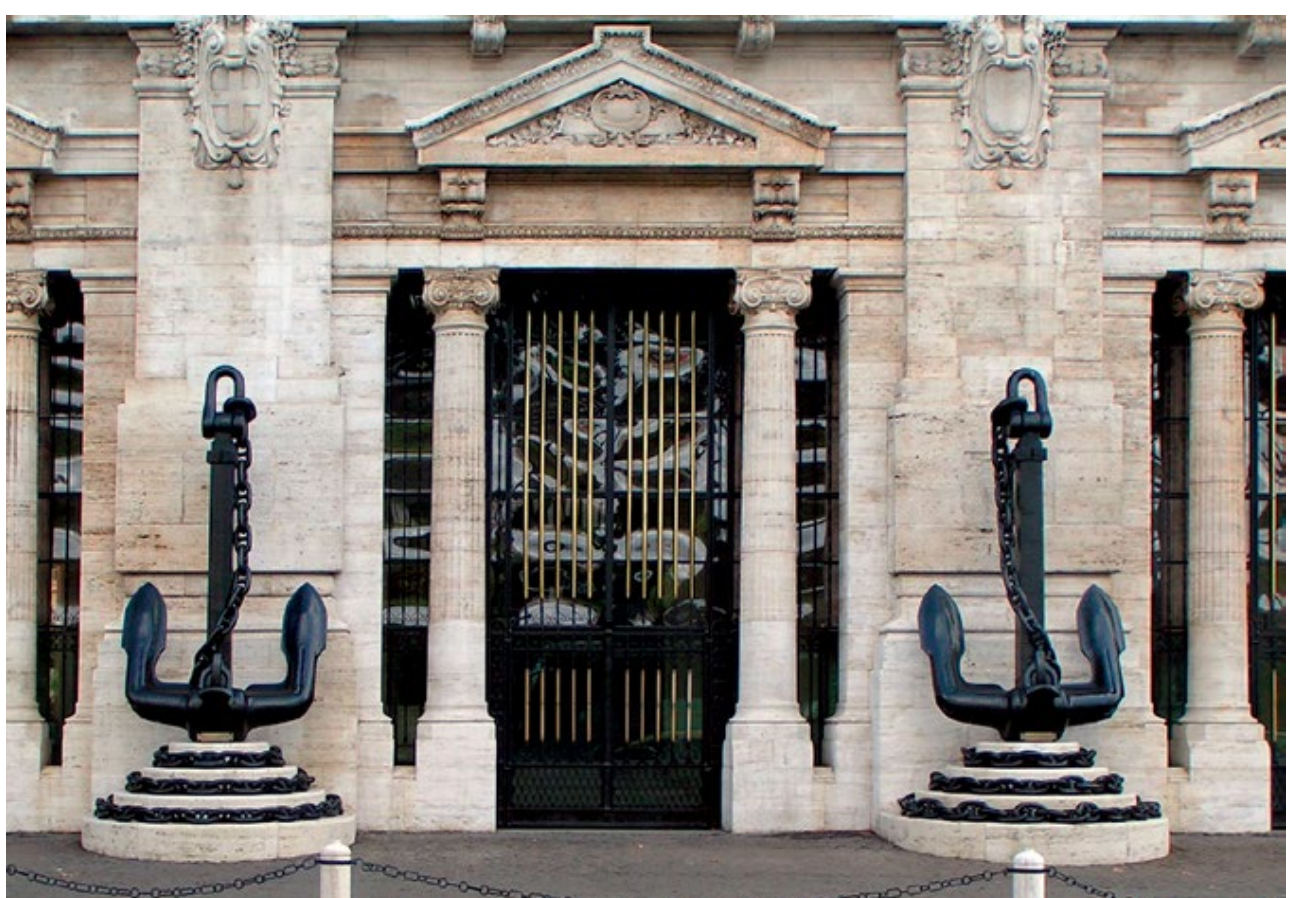

ZUM ANDENKEN AN

JANKO VUKOVIC DE PODKAPELSKY

K. U.R. LINIENSCHIFFSKAPIDN

KOMMANDANT S.M.S.VIRIBUS UNIHS

DER AM I NOVEMBER 1918

IM HAFEN VON POLA

DEN HELDENTOD FAND.

Janko Vukc

- Podkapelski

in the Austro-

Hungarian Navy cemetary in Pula.

Source:

Matjaž Bizjak,

2008

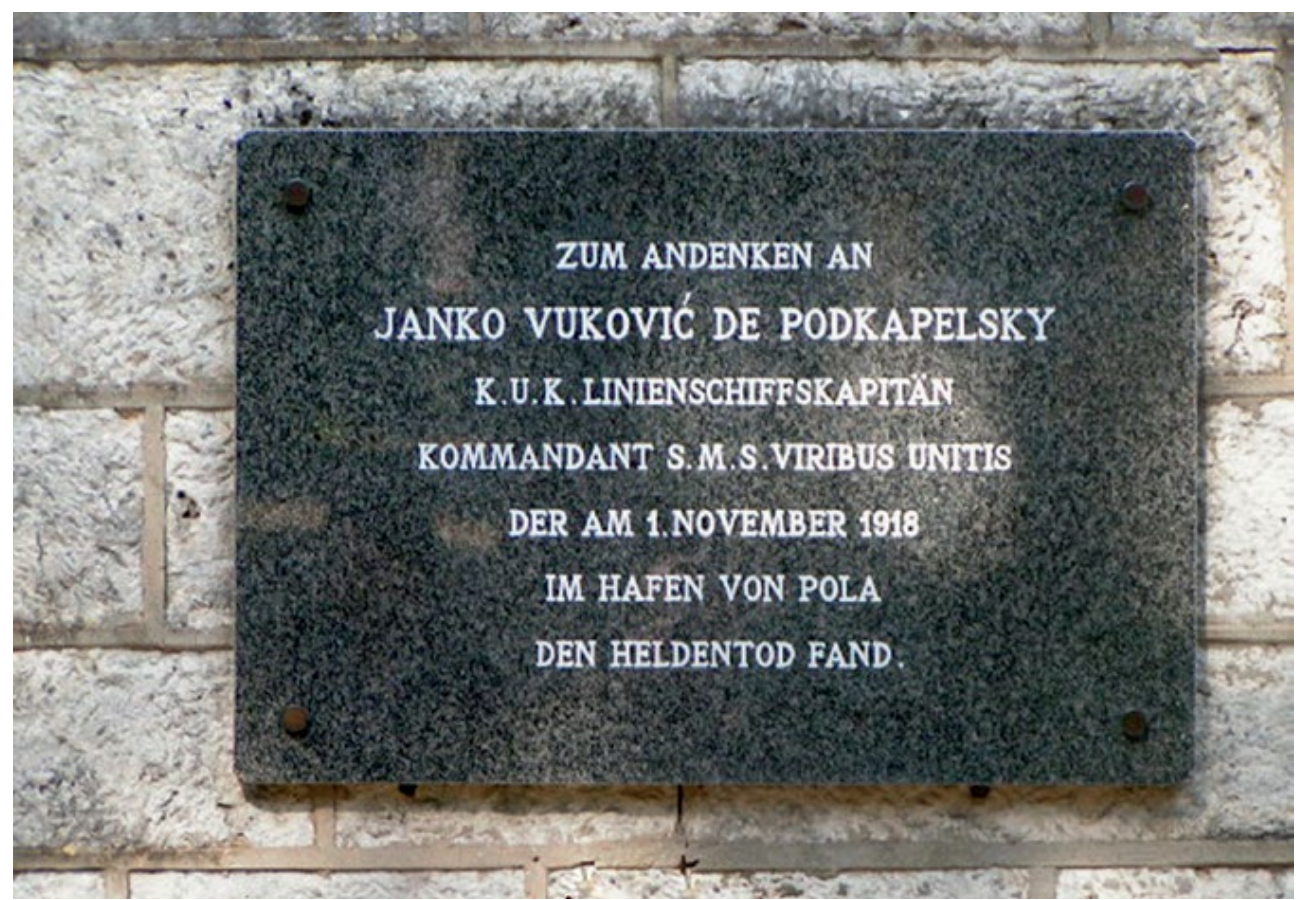


Slika 9: Načrt poti od Benetk proti Pulju

Vir: AUSMM

Figure 9:

Map of the route from Venice to Pula.

Source: AUSMM

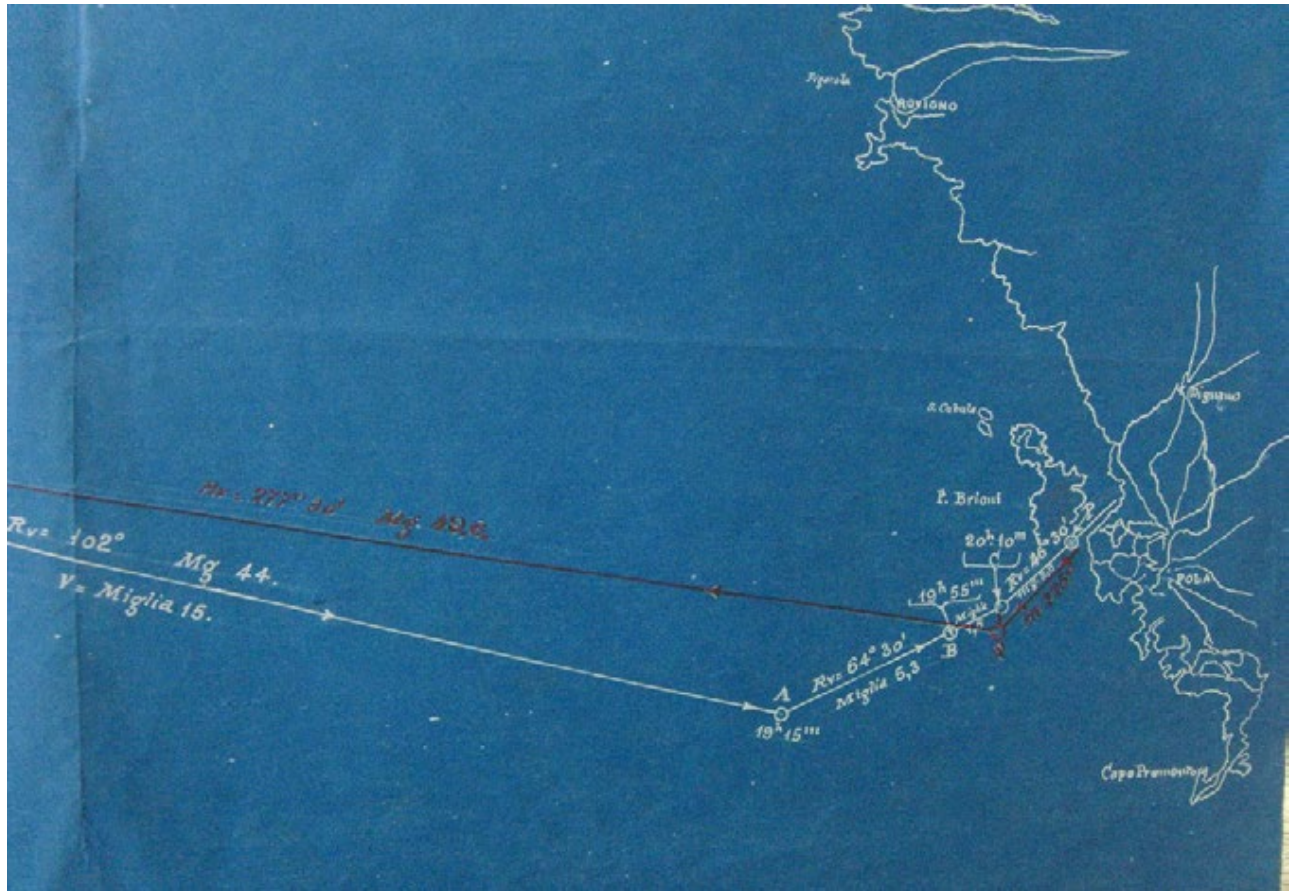

Slika 10: Avstro-ogrska bojna ladja Viribus Unitis

Povijesni i pomorski muzej Istre

Figure 10: Austro-

Hungarian battleship Viribus Unitis

Source:

Povjesni i pomorski muzej Istre (Historical and Maritime Museum of Istria)

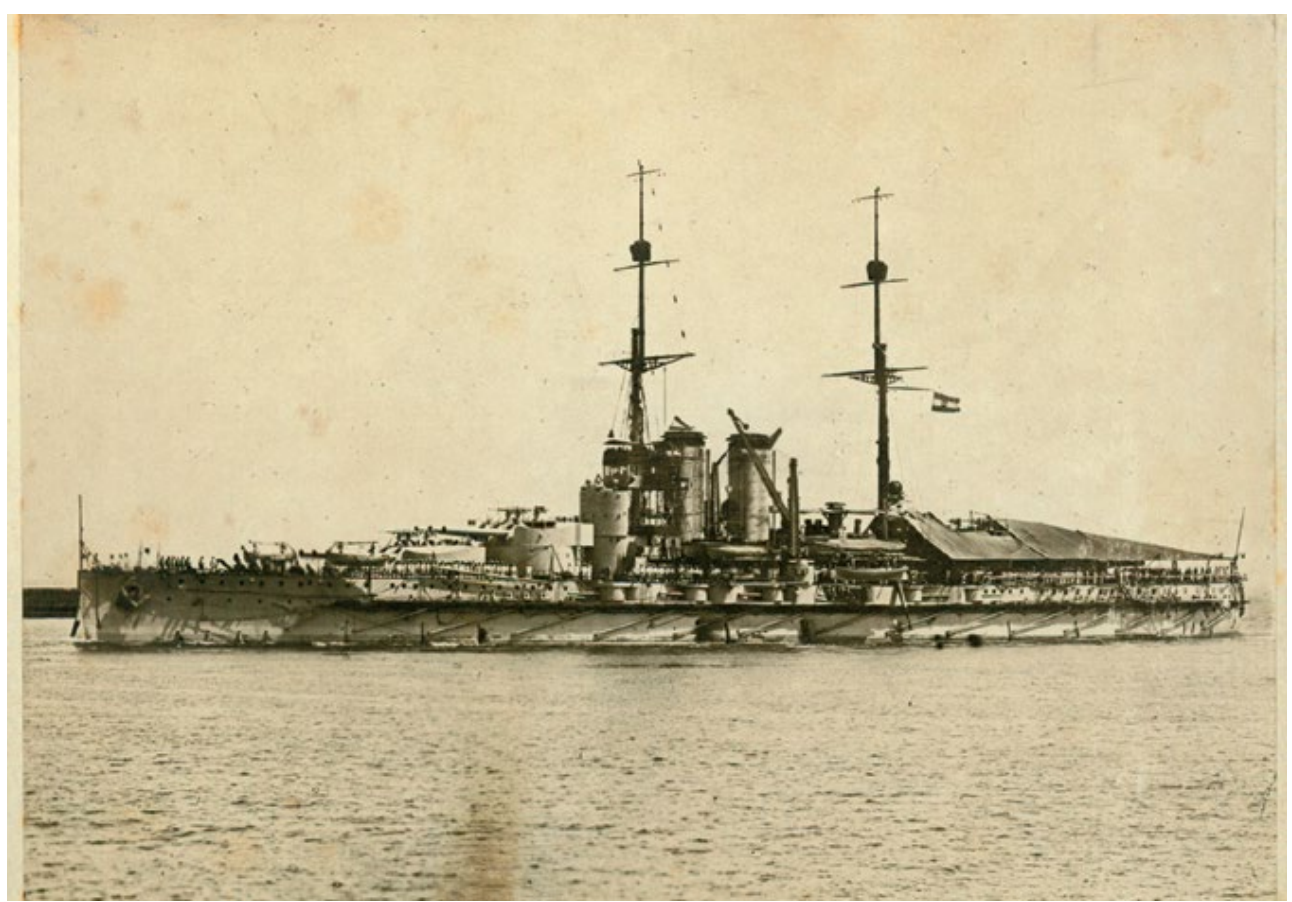


Slika 11:

Cesar Karel

med obiskom

na Virbus Unitis

leta1917

Vir: Povijesni i pomorski muzej

Istre

Figure 11:

Emperor Charles

during the visit

of Viribus Unitis

in 1917

Source: Povijesni

i pomorski

muzej Istre

(Historical

and Maritime

Museum of

Istria)

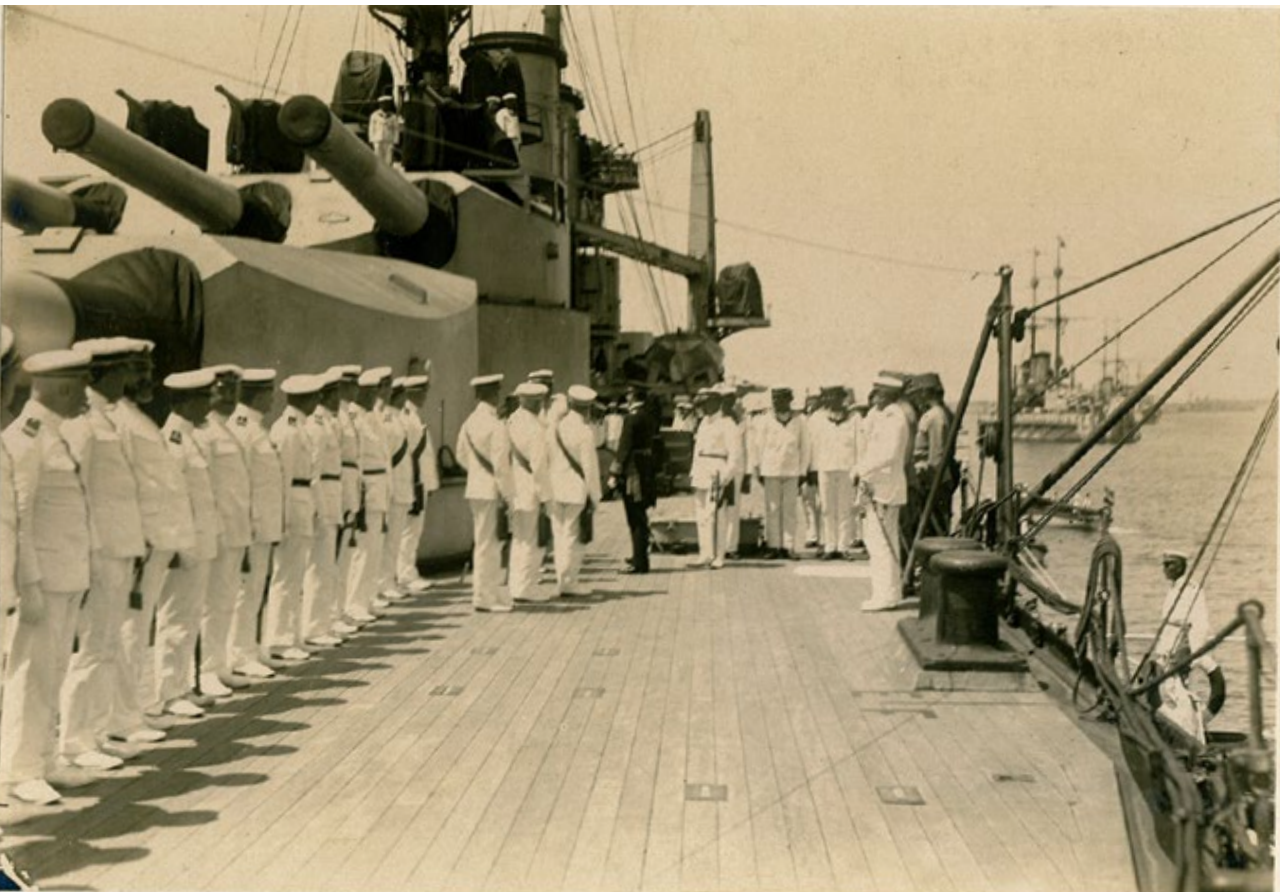

Slika 12:

Avstro-ogrska

bojna ladja

Viribus Unitis

Vir: Povijesni i

pomorski muzej

Istre

Figure 12:

Austro-

Hungarian

battleship

Viribus Unitis

Source: Povjesni

i pomorski

muzej Istre

(Historical

and Maritime

Museum of

Istria)

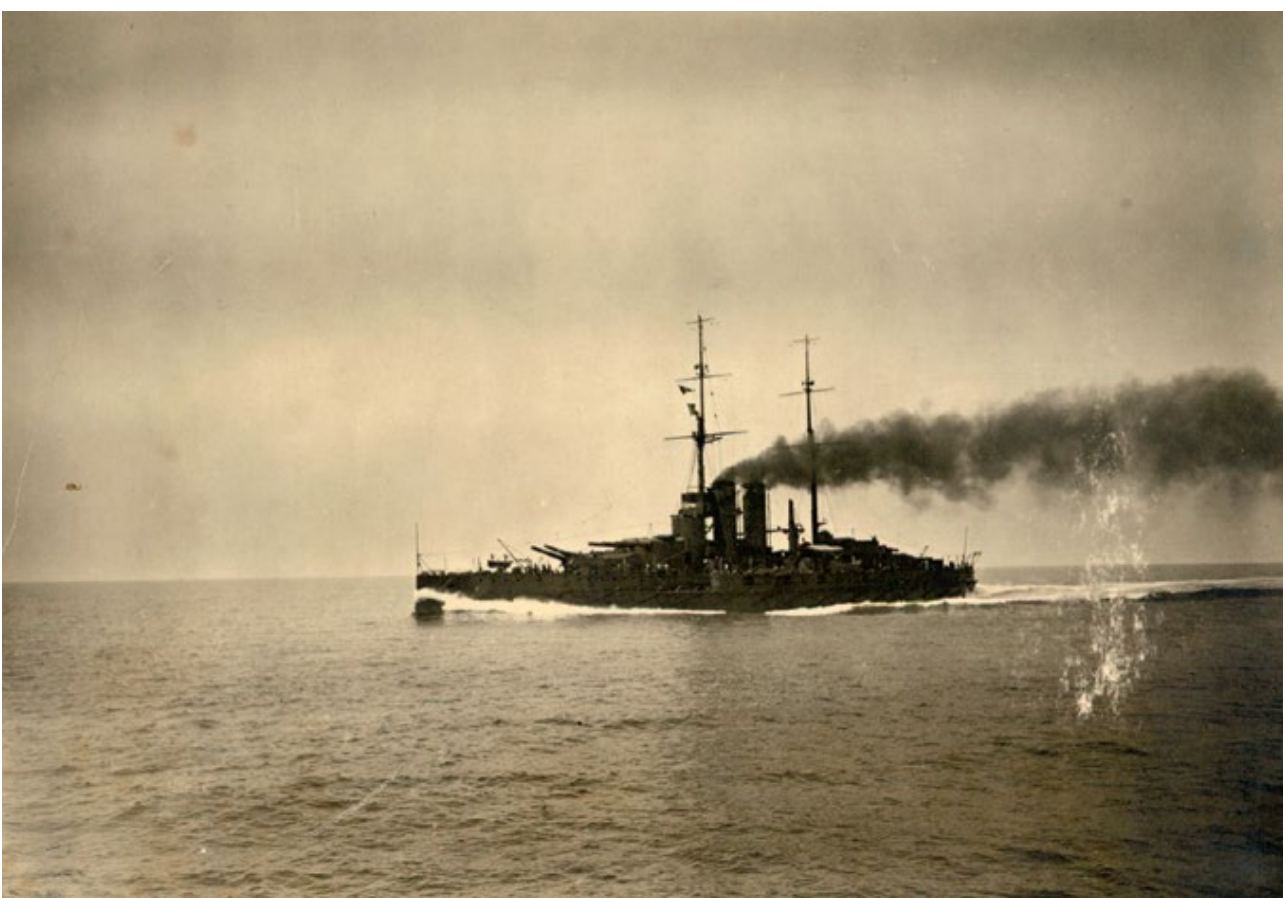

